J. Amer. Soc. Hort. SCI. 121(1): 105-114. 1996.

\title{
How Nitrogen Supply Affects Growth and Nitrogen Uptake, Use Efficiency, and Loss from Citrus Seedlings
}

\author{
John D. Lea-Cox ${ }^{1}$ and James P. Syvertsen \\ Citrus Research and Education Center, University of Florida, Institute of Food and Agricultural Sciences, \\ 700 Experiment Station Road, Lake Alfred, FL 33850-2299
}

Additional index words. ammonium nitrate, ${ }^{15} \mathrm{NO}_{3},{ }^{15} \mathrm{NH}_{4}, \mathrm{~N}$ partitioning, $\mathrm{CO}_{2}$ assimilation, leaching loss, uptake-efficiency,
Citrus aurantium, C. reticulate, C. volkameriana, Poncirus trifoliata $\times$ C. paradisi

\begin{abstract}
We examined how $\mathrm{N}$ supply affected plant growth and $\mathrm{N}$ uptake, allocation and leaching losses from a fine sandy soil with four Citrus rootstock species. Seedlings of 'Cleopatra' mandarin (Citrus reticulata Blanco) and 'Swingle' citrumelo (C. paradisi $\times$ P. trifoliata) were grown in a glasshouse in 2.3-liter pots of Candler fine sand and fertilized weekly with a complete nutrient solution containing $200 \mathrm{mg} \mathrm{N} /$ liter $(20 \mathrm{mg}$ N/week $)$. A single application of ${ }^{15} \mathrm{NH}_{4}{ }_{4}^{15} \mathrm{NO}_{3}(17.8 \%$ atom excess ${ }^{15} \mathrm{~N}$ ) was substituted for a normal weekly $\mathrm{N}$ application when the seedlings were 22 weeks old (day $\mathrm{O}$ ). Six replicate plants of each species were harvested at $0.5,1.5,3.5,7,11$, and 30 days after ${ }^{15} \mathrm{~N}$ application. In a second experiment, $\mathrm{NH}_{4} \mathrm{NO}_{3}$ was supplied at 18,53 , and $105 \mathrm{mg}$ N/week to 14-week-old 'Volkamer' lemon (C. volkameriana Ten. \& Pasq.) and sour orange (C. aurantium L.) seedlings in a complete nutrient solution for 8 weeks. A single application of ${ }^{15} \mathrm{NH}_{4}^{15} \mathrm{NO}_{3}\left(23.0 \%{ }^{15} \mathrm{~N}\right.$ ) was substituted at 22 weeks (day 0 ), as in the first experiment, and seedlings harvested 3,7, and 31 days after ${ }^{15} \mathrm{~N}$ application. Nitrogen uptake and partitioning were similar among species within each rate, but were strongly influenced by total $\mathbf{N}$ supply and the $\mathbf{N}$ demand by new growth. There was no ${ }^{15} \mathrm{~N}$ retranslocation to new tissue at the highest $\left(105 \mathrm{mg} \mathrm{N} /\right.$ week) rate, but $\mathrm{N}$ supplies below this rate limited plant growth without short-term ${ }^{15} \mathrm{~N}$ reallocation from other tissues. Leaf $\mathrm{N}$ concentration increased linearly with $\mathrm{N}$ supply up to the highest rate, while leaf chlorophyll concentration did not increase above that at $53 \mathrm{mg} \mathrm{N} /$ week. Photosynthetic $\mathrm{CO}_{2}$ assimilation was not limited by $\mathrm{N}$ in this study; leaf $\mathrm{N}$ concentration exceeded $100 \mathrm{mmol} \cdot \mathrm{m}^{-2}$ in all treatments. Thus, differences in net productivity at the higher $\mathbf{N}$ rates appeared to be a function of increased leaf area, but not of leaf $\mathbf{N}$ concentration. Hence, $\mathbf{N}$ use efficiency decreased significantly over the range of $\mathrm{N}$ supply, whether expressed either on a gas-exchange or dry weight basis. Mean plant ${ }^{15} \mathrm{~N}$ uptake efficiencies after 31 days decreased from $60 \%$ to $47 \%$ of the ${ }^{15} \mathrm{~N}$ applied at the 18,20, and $53 \mathrm{mg} / \mathrm{Neek}$ rates to less than $33 \%$ at the $105 \mathrm{mg} \mathrm{N} /$ week rate. Leaching losses increased with $\mathrm{N}$ rate, with plant growth rates and the subsequent $\mathrm{N}$ requirements of these Citrus species interacting with residual soil $\mathbf{N}$ and potential leaching loss.
\end{abstract}

Minimum $\mathrm{N}$ concentrations in irrigation solutions, required to support high growth rates of containerized Citrus trees, are between 10 and $25 \mathrm{mg} \mathrm{N} /$ liter in various substrates under warm, highirradiance greenhouse conditions (Chapman and Liebig, 1937; Haas, 1937; Lea-Cox, 1989; Maust and Williamson, 1994). However, since fertilizer solutions were applied to excess to ensure leaching and to avoid the accumulation of salts in all these studies, actual $\mathrm{N}$ requirements of Citrus species are not known. Bitcover and Wander (1950) calculated (by difference from $\mathrm{N}$ applied and $\mathrm{N}$ leached) that from $22 \%$ to $44 \%$ of the applied ammonium- or nitrate-N, respectively, was taken up within 10 minutes by budded Citrus trees in gravel. This implied a very high $\mathrm{N}$ uptake-efficiency, but their results ignored any other potential $\mathrm{N}$ losses. Nitrogen uptake-efficiency over 4 weeks in lemon cuttings was $72 \%$ of ${ }^{15} \mathrm{NH}_{4} \mathrm{NO}_{3}$ applied at $97 \mathrm{mg} \mathrm{N} /$ week but only $39 \%$ when applied at $485 \mathrm{mg} \mathrm{N} /$ week (Wallace, 1954). Maust and Williamson (1994) assumed that all ${ }^{15} \mathrm{~N}$ supplied to 'Hamlin' orange [C.

Received for publication 27 Mar. 1995. Accepted for publication 19 Sept. 1995. Florida Agricultural Experiment Station Journal series no. R-004467. Research supported by the U.S. Geological Survey (USGS), Dept. of the Interior, under USGS award number 1408-000 $1-\mathrm{G}$ 1905, The views and conclusions contained in this document are those of the authors and should not be interpreted as necessarily representing the official policies, either expressed or implied, of the U.S. government. J. Lea-Cox thanks the Univ. of Florida Foundation Herlong graduate assistant supplement for financial support. We thank Martin L. Smith, Jr., for invaluable assistance. The cost of publishing this paper was defrayed in part by the payment of page charges. Under postal regulations, this paper therefore must be hereby marked advertisement solely to indicate this fact.

'To whom reprint requests should be addressed, Present address: NASA-Life Sciences, Mail Code MD-RES, Kennedy Space Center, FL 32899, sinensis (L.) Osb.] budded on Carrizo citrange [C. sinensis (L.) Osb. $\times$ Poncirus trifoliata (L.) Raf.] seedlings would be taken up completely within 7 days, based on their fertilization regime. They concluded that $17 \mathrm{mg} \mathrm{N} /$ day (119 mg N/week) was the critical $\mathrm{N}$ concentration in solution to maintain adequate continuous growth of young trees on the two rootstock. No study has directly measured uptake rates of Citrus rootstock with varying growth rates, while simultaneously considering the effects of the absolute quantity of $\mathrm{N}$ (mg N/week) supplied to the plant over time on residual soil $\mathrm{N}$ and leaching losses.

Nitrogen deficiency can limit growth (Lea-Cox, 1989; Maust and Williamson, 1994; Wallace, 1954) and increase partitioning of carbohydrates and nutrient ions to roots (Tolley-Henry and Raper, 199 1). This can be reflected in increased root growth, $\mathrm{N}$ acquisition capacity and $\mathrm{N}$ uptake per gram of root (Rufty et al., 1990). Nitrogen deficiency-induced alterations in the distribution of assimilates between the shoot and root have a strong and rapid effect on decreasing the rate of leaf area development (Radin and Boyer, 1982), more so than plant dry weight (Ingestad and Lund, 1979). A constant relative growth rate, along with increasing $\mathrm{N}$ supply, ensures that leaf nutrient concentrations will remain constant overtime (Ägren, 1985). Any decline in leaf $\mathrm{N}$ concentration can indicate that nutrient supply is limiting the maximum potential growth rate of plants (McDonald et al., 1991).

Low leaf $\mathrm{N}$ can also limit net photosynthetic assimilation of $\mathrm{CO}_{2}\left[\mathrm{ACO}_{2}\right]$ (DeJong, 1982; DeJong and Phillips, 1981; Hesketh et al. 1981; Mooney et al., 1978; Syvertsen, 1987). Photosynthates are produced in proportion to the amount of $\mathrm{N}$ used to construct leaf area, chlorophyll (Sinclair, 1992), and in particular the large 
proportion of leaf $\mathrm{N}$ that is contained in ribulose- 1,5-bisphosphate carboxylase-oxygenase [rubisco] (Moreno and Garcia-Martinez, 1984). Above a certain leaf $\mathrm{N}$ concentration, $\mathrm{N}$ does not limit $\mathrm{ACO}_{2}$ (Lugg and Sinclair, 1981; Evans, 1989) and the functional relationship between increasing leaf $\mathrm{N}$ concentration and $\mathrm{ACO}_{2}$ becomes less clear. Less than $10 \%$ of leaf rubisco is active at leaf $\mathrm{N}$ concentrations above $200 \mathrm{mmol} \cdot \mathrm{m}^{-2}$, based on $\mathrm{ACO}_{2}$ rates from sun leaves of Citrus paradisi and C. limon leaves (Lloyd et al., 1992).

Any $\mathrm{N}$ applied in excess of the amount of $\mathrm{N}$ taken up by Citrus species increases soil $\mathrm{N}$ concentration and the potential of leaching of $\mathrm{NO}_{3}$ from the soil-plant system. The objectives of this greenhouse study were to define the $\mathrm{N}$ requirement of various Citrus rootstock species with contrasting growth rates, and to determine how $\mathrm{N}$ supply affected $\mathrm{N}$ partitioning, $\mathrm{N}$ use efficiency and the $\mathrm{N}$ leaching loss potential from sandy soils. These species represent rootstock that are commonly used throughout the world for adaptation to varying edaphic and environmental conditions, ultimately to improve fruit quality.

\section{Materials and Methods}

\section{Experiment 1}

Plant treatments. Seedlings of two Citrus rootstock species of contrasting growth rates, slow-growing 'Cleopatra' mandarin (Citrus reticulate Blanco $=\mathrm{CM}$ ) and fast-growing 'Swingle' citrumelo [C. paradisi Macf. $\times$ Poncirus trifoliata (L.) Raf. $=$ SC], were grown from seed in a glasshouse covered with $50 \%$ shadecloth from March to October, 1990. Thirty-six, 16-week-old seedlings of each species were selected for uniformity and individually transplanted into 2.3-liter plastic pots of pasteurized Candler fine sand (Typic Quartzipsamments), which had been steam pasteurized 2 days previously at $120 \mathrm{C}$ for $8 \mathrm{~h}$. All plants received a weekly application of about $250 \mathrm{ml}$ of a commercial [20N-(urea, $\mathrm{NH}_{4}$, and $\mathrm{NO}_{3}$ ) $-8.7 \mathrm{P}-16.7 \mathrm{~K}$ ] nutrient solution (fertigation) at a concentration of $200 \mathrm{mg} \mathrm{N} /$ liter (about $50 \mathrm{mg} \mathrm{N} /$ week) for the next 4 weeks. The average $(n=6)$ void volume of the soil in the pots was determined to be $350 \mathrm{ml}$ (i.e., the volume of air space in the soil) at container capacity. Plants were watered to excess every other day, following standard citrus nursery practice, so that leaching of the pots occurred between fertigations. Beginning 2 weeks before the ${ }^{15} \mathrm{~N}$ application, $100 \mathrm{ml}$ of a $1 \mathrm{~N}-0.2 \mathrm{P}-1 \mathrm{~K}$ nutrient solution, using $\mathrm{NH}_{4} \mathrm{NO}_{3}$ as the sole $\mathrm{N}$ source, was applied weekly at $200 \mathrm{mg} \mathrm{N} /$ liter (20 mg N/week) to each plant, substituting for a normal irrigation. During this period, average daily photosynthetic photon flux (PPF) was about $650 \mu \mathrm{mol} \cdot \mathrm{m}^{-2} \cdot \mathrm{s}^{-1}$, minimum glasshouse air temperatures ranged between $13-18 \mathrm{C}$ and maxima $25-34 \mathrm{C}$, relative humidity $(\mathrm{RH})$ varied between $30 \%$ to $100 \%$ and vapor pressure deficit (VPD) from 0-3.7 kpa.

Application of ${ }^{15} \mathrm{~N}$. On day 0 , when the plants were 22 weeks old, a single application of 17.81910 atom excess ${ }^{15} \mathrm{NH}_{4}^{15} \mathrm{NO}_{3}$ at 200 $\mathrm{mg} \mathrm{N} / \mathrm{liter}$ was substituted for the $\mathrm{N}$ in the normal weekly fertigation in $100 \mathrm{ml}$ water (=20 mg total $\mathrm{N}$ per plant). Two days before the application of ${ }^{15} \mathrm{~N}$, pots were thoroughly leached with distilled water, and then individually weighed at container capacity, when completely drained. The $100 \mathrm{ml}$ volume of the ${ }^{15} \mathrm{~N}$ application was enough solution to bring the soil to near container capacity (by weight) but insufficient to result in any leaching from the pot. Pots were weighed every 2 days thereafter and the weight of water lost through evapotranspiration was replaced with distilled water without leaching occurring. Seedlings were arranged in a completely randomized design. Six of the 36 seedlings of each species were randomly selected for harvest at $0.5,1.5,3.5,7,11$, and 30 days after ${ }^{15} \mathrm{~N}$ application (day 0 ). Three fertigations were applied to the remaining seedlings at days 8,16 and 22 , using ${ }^{14} \mathrm{~N}$ Nat $200 \mathrm{mg}$ N/liter.

Plant analysis. All seedlings were tagged on day 1 just below the shoot tip to determine the new growth (NG) portion at each harvest day following the application of ${ }^{15} \mathrm{~N}$. In addition, the terminal leaves of the 12 seedlings that were selected on day 1 to be harvested on day 30 were additionally tagged on days 15 and 29 . Individual leaf lengths and widths were measured on these days so that relative growth rates (RGRs) could be calculated. A regression equation $\left(r^{2}=0.97\right)$ predicted leaf areas on all measurement days by regressing the leaf length and width measurements (Syvertsen, 1985) on day 29 with the individual leaf areas measured on day 30.

On each of the 6 harvest days, the fibrous root (FR), taproot (TR), stem (S), fully expanded mature leaves (ML), and new shoot growth $(\mathrm{NG}=$ young shoot plus associated immature leaves initiated since ${ }^{15} \mathrm{~N}$ application) fractions of each plant were weighed after drying at $60 \mathrm{C}$ for $48 \mathrm{~h}$. At each harvest, the FR length of each plant was determined before drying, using a line intercept method (Tennant, 1975). Tissue fractions were milled (Cyclotec 1093, Tecator, Sweden) and total $\mathrm{N}$ concentrations of well-mixed tissue samples were analyzed by combustion and gas chromatography using a carbon/nitrogen analyzer (NA 1500; Carlo Erba, Fison Instruments, Paramus, N.J.). A mass spectrometer (VG602E; Vacuum Generators, Winsford, England) connected in series to the nitrogen analyzer determined the ${ }^{14} \mathrm{~N}:{ }^{15} \mathrm{~N}$ ratio. Total tissue ${ }^{15} \mathrm{~N}$ contents (mg per tissue) were calculated using the method of Cabrera and Kisel(1989). Samples of about $250 \mathrm{mg}$ of ML tissue were ashed for $5 \mathrm{~h}$ at 500C (Gaines and Mitchell, 1979) and concentrations of cations were determined by inductively coupled plasma (ICP) analysis on a Perkin-Elmer (Norwalk, Corm.) Plasma 40 , using a sequential scanning method.

Leachate and soil analysis. Just before each harvest, pots were leached with $400 \mathrm{ml}$ of distilled water and the leachate collected. This resulted in a leachate volume of about 200-300 ml, from which a $20 \mathrm{ml}$ sub-sample was immediately frozen until analyzed for N. After leaching, about $100 \mathrm{~g}$ of well-mixed soil from each pot was frozen for subsequent $\mathrm{N}$ analysis. Inorganic soil $\mathrm{N}$ was extracted from $50 \mathrm{~g}$ of soil with two consecutive $75-\mathrm{ml}$ aliquots of $2 \mathrm{M} \mathrm{KCl}$ (Bremner, 1965), which were then combined into a single 150-ml sample. The concentrations of total $\mathrm{NH}_{4}-\mathrm{N}$ and $\mathrm{NO}_{3}-\mathrm{N}$ in the leachate fractions and $\mathrm{KC} 1$ extracts were analyzed using a rapid flow calorimetric autoanalyzer (Clesceri et al., 1989). Since solid samples are required for ${ }^{14} \mathrm{~N}:{ }^{15} \mathrm{~N}$ ratio determination by the mass spectrometer, ${ }^{15} \mathrm{NH}_{4}-\mathrm{N}$ and ${ }^{15} \mathrm{NO}_{3}-\mathrm{N}$ fractions were recovered in separate 5-ml aliquots of boric acid by steam distillation of the soil and leachate solutions (Bremner and Keeny, 1966; Hauck and Bremner, 1976). The boric acid aliquots were then reduced to dryness before analysis using the mass spectrometer.

\section{Experiment 2}

Plant treatments. This experiment duplicated Expt. 1, except two different rootstock species, again of contrasting growth rate, were fertilized with three different rates of N. Fifty-four 14-weekold seedlings each of slow-growing sour orange (C. aurantium L. = SO) and fast-growing 'Volkamer' lemon (C. volkameriana Ten and Pasq. = VL) were grown in 2.3-liter pots of pasteurized Candler fine sand in the glasshouse, covered with $50 \%$ shadecloth, from March to October, 1991. Eighteen plants of each species were fertilized with $\mathrm{NH}_{4} \mathrm{NO}_{3}$ at either 17.5,52.5, and $105 \mathrm{mg} \mathrm{N} /$ week, supplied in $350 \mathrm{ml}$ of distilled water $(=50,150$, or $300 \mathrm{mg} \mathrm{N} /$ liter) for the next 8 weeks in a completely randomized design. Phosphorus, $\mathrm{K}$ and $\mathrm{S}$ were supplied to all seedlings at 50, 300, and 45 $\mathrm{mg} \cdot$ liter $^{-1}$ respectively, in all solutions. All irrigations between 
fertigations were applied to excess, as in Expt. 1, to ensure leaching and avoid any accumulation of salts. Average daily PPF was about $700 \mu \mathrm{mol} \cdot \mathrm{m}^{-2} \cdot \mathrm{s}^{-1}$, minimum glasshouse air temperatures ranged between $14-20 \mathrm{C}$ and maxima $24-32 \mathrm{C}$, RH from $40 \%$ to $100 \%$, and VPD from $0-3.3 \mathrm{kPa}$.

Application of ${ }^{15} \mathrm{~N}$. The ${ }^{15} \mathrm{~N}$ was applied to all treatments exactly as described in 'Expt. 1. All pots were thoroughly leached and weighed at container capacity before the ${ }^{15} \mathrm{~N}$ application, which again substituted for the ${ }^{14} \mathrm{~N}$ in a normal weekly fertigation when the plants were 22 weeks old. The isotopic enrichment of the ${ }^{15} \mathrm{NH}_{4}^{15} \mathrm{NO}_{3}$ varied slightly for each rate, i.e., $23.43 \%, 23.03 \%$, and $22.8 \%$ atom excess for the 18, 53, and $105 \mathrm{mg}$ treatments, respectively. Additional complete fertilizations at each rate were applied (using ${ }^{14} \mathrm{~N}$ ) on days 7 (after plant harvest), 15, and 23 without leaching. Plant dry weight analysis and nutrient ICP analyses after harvest were determined as in Expt. 1.

Plant analysis. Six randomly selected seedlings of each species and $\mathrm{N}$ rate were harvested on days 3,7 , and 31 after ${ }^{15} \mathrm{~N}$ application (day 0 ). The terminal leaves of all seedlings were tagged on day 1 as in Expt. 1. In addition, the leaves of the 18 seedlings of each species randomly assigned at day 0 to the 31-day harvest were retagged on days 11,18 , and 30 . Individual leaf lengths and widths
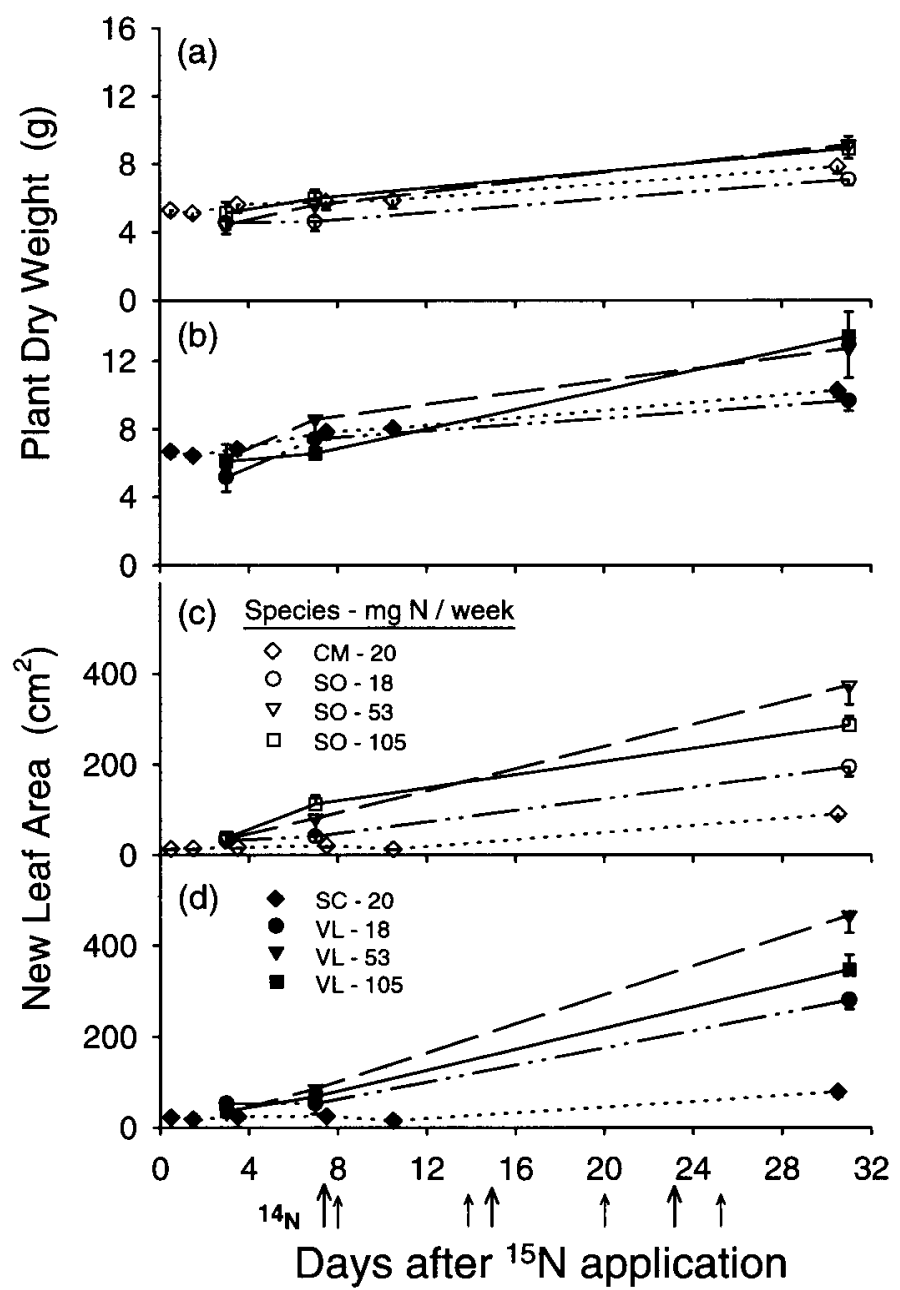

Fig. 1. Total plant dry weight $(\mathrm{n}=6)$ of $(\mathbf{a})$ 'Cleopatra' mandarin $(\mathrm{CM})$ and sour orange (SO), (b) 'Swingle' citrumelo (SC) and 'Volkamer' lemon (VL) seedlings; new leaf area $(n=6)$ of (c) CM, SO seedlings, and (d) SC, VL seedlings for 31 days after application of ${ }^{15} \mathrm{~N}$ at each respective $\mathrm{N}$ rate (mg N/week). "Nitrogen applications at each rate indicated on the $\mathrm{x}$-axis by small arrows (Expt. 1) and large arrows (Expt. 2). Error bars represent 1 SE from the mean. No error bar indicates a SE smaller than the symbol size. were measured on these days so that relative growth rates could be calculated using predicted leaf areas, as described in Expt. 1.

The youngest fully expanded leaf, selected on day 1 , of each seedling to be harvested on day 31 was tagged for repeated measurement of $\mathrm{ACO}_{2}$ on days 17, 18, 25, and 28, performed with a portable photosynthesis system (6200; LI-COR, Lincoln, Neb.) with a 1-liter measurement cuvette operated in closed mode. All measurements were made between 0900-1200 HR when photon flux density (PPF) levels were between $700-1400 \mu \mathrm{mol} \cdot \mathrm{m}^{-2} \cdot \mathrm{s}^{-1}$ (above light saturation). Leaf temperatures in the cuvette ranged from 31-37C with leaf-to-air vapor pressure differences from 2.2$3.6 \mathrm{kPa}$. Total leaf chlorophyll concentrations were determined (Moran and Porath, 1980) from two 10-mm discs removed at harvest on day 31 from mid-lamina of the leaf used for gasexchange measurements.

Whole-plant transpiration per unit leaf area was calculated from daily weight loss of the 31-day-harvest seedlings on days 17, 18, 25,28 , and 30 . Root hydraulic conductivity of each species at the 18 and $53 \mathrm{mg} \mathrm{N}$ rates were measured on day 31, using a pressure chamber technique (Graham and Syvertsen, 1984). Briefly, the plant stem was cut $6 \mathrm{~cm}$ above the soil line and the pot with intact root system pressurized to a constant $0.38 \mathrm{MPa}$. After an initial equilibration time of 15 rein, the weight of xylem fluid that exuded from the cut stump during three 5-rein periods was measured. The hydraulic conductivity of roots was expressed as the weight of exudate per unit length of fibrous root per unit time and pressure $\left(\mu \mathrm{g} \cdot \mathrm{m}^{-1} \cdot \mathrm{s}^{-1} \mathrm{M} \mathrm{P} \mathrm{a}^{-1}\right)$.

Leachate and soil analysis. Leachate and soil analysis were as in Expt. 1, except that pots were leached with a larger volume (930 $\mathrm{ml}$ ) of distilled water to ensure total leaching. The electrical conductivity (EC) of all leachates was measured. Soil temperatures were recorded at 0.5 -h intervals throughout the 30 -day period using an Omnidata (Logan, Utah) datapod (model DP211) with a thermistor probe in the middle of the pot. Overall, soil temperatures lagged behind air temperatures by about $3 \mathrm{~h}$, between the range 14 to $30 \mathrm{C}$.

Statistical analysis. Plant tissue dry weight and $\mathrm{N}$ data from Expts. 1 and 2 were each analyzed separately. Within each experiment, data were tested for significant differences within each harvest date, using a factorial analysis of variance with six replicate seedlings per treatment in a completely randomized design. When a significant $(P<0.05)$ interaction between rates occurred in the ANOVA, regression analysis was used to determine the relationship between individual treatments (Montgomery, 1984). Percentage data from each experiment were transformed before analysis by taking the arcsine of the square root of the value (Ott, 1988). Gas exchange and WPT data (Expt. 2) were analyzed using a repeated measures analysis (Littell, 1989), since all data were collected from the same plants on repeated days.

\section{Results}

Growth. For ease of comparison, the rootstock species were grouped in some tables and figures according to their respective growth rates. Where appropriate, $t$ tests were used to compare results between experiments. 'Cleopatra' mandarin and SO had smaller total plant dry weight increases over the ${ }^{15} \mathrm{~N}$ uptake period (Fig. 1a) than SC and VL seedlings of the same age (Fig. lb) at all $\mathrm{N}$ rates, even though the initial dry weights of all seedlings were comparable at day 3 . There was no difference in total dry weight among species of similar growth rate over the experimental period at $20 \mathrm{mg}$ or $18 \mathrm{mg} \mathrm{N} /$ week (parallel slopes in Fig. $1 \mathrm{a}$ and b), but the higher $\mathrm{N}$ rates produced greater dry weights (Fig. $1 \mathrm{a}$ and $\mathrm{b}$ ) and 
Table 1. Shoot: root ratio (dry weight basis), new leaf growth dry weight: leaf area ratio (DW/LA), fibrous root (FR) length, and specific root length (SRL) of Cleopatra mandarin $(\mathrm{CM})$, Swingle citrumelo $(\mathrm{SC})$ seedlings $(\mathrm{n}=6)$ in Expt. 1, and sour orange (SO), Volkamer lemon (VL) seedlings in Expt. 2 at day 31.

\begin{tabular}{|c|c|c|c|c|}
\hline \multicolumn{5}{|c|}{ New leaf growth } \\
\hline Species-N rate & $\begin{array}{c}\text { Shoot : root } \\
\left(\mathrm{g} \cdot \mathrm{g}^{-1}\right)\end{array}$ & $\begin{array}{c}\mathrm{DW} / \mathrm{LA} \\
\left(\mathrm{g} \cdot \mathrm{m}^{-2}\right)\end{array}$ & $\begin{array}{l}\text { FR length } \\
(\mathrm{m})\end{array}$ & $\begin{array}{c}\text { FR SRL } \\
\left(\mathrm{m} \cdot \mathrm{g}^{-1}\right)\end{array}$ \\
\hline$\overline{\mathrm{CM}-20 \mathrm{mg}}$ & 3.18 & 83.8 & 17.03 & 2.06 \\
\hline $\mathrm{SC}-20 \mathrm{mg}$ & 2.03 & 72.0 & 21.95 & 1.30 \\
\hline \multicolumn{5}{|l|}{$t$ test: ( $P$ values $)$} \\
\hline Species & $<0.001$ & $<0.001$ & $<0.001$ & $<0.001$ \\
\hline SO-18 mg & 1.87 & 62.7 & 24.08 & 1.67 \\
\hline $\mathrm{SO}-53 \mathrm{mg}$ & 3.01 & 59.6 & 27.87 & 2.05 \\
\hline SO-105 mg & 2.60 & 66.6 & 25.13 & 1.69 \\
\hline VL-18 mg & 2.05 & 54.1 & 34.99 & 1.99 \\
\hline VL-53 mg & 2.95 & 57.4 & 39.36 & 2.19 \\
\hline VL-105 mg & 2.62 & 63.9 & 35.64 & 1.77 \\
\hline \multicolumn{5}{|l|}{ Anova: ( $P$ values $)$} \\
\hline Species & 0.65 & 0.02 & $<0.001$ & $<0.001$ \\
\hline Rate & $<0.001$ & $<0.01$ & 0.42 & $<0.001$ \\
\hline Species $\times$ rate & 0.62 & 0.25 & 0.99 & 0.10 \\
\hline
\end{tabular}

more leaf area (Fig. $1 \mathrm{c}$ and d). Although VL and SC were larger than $\mathrm{CM}$ and SO by day 31 , total plant dry weight of plants did not differ within each group, whether fertilized at the 53 or $105 \mathrm{mg} \mathrm{N} /$ week rates (Fig. $1 \mathrm{a}$ and $\mathrm{b}$ ).

SO and VL in Expt. 2 developed more new leaf area (Figs. $1 \mathrm{c}$ and d) and increased shoot : root ratio (Table 1 ) with an increase in $\mathrm{N}$ rate. The reduction in new leaf area of both species at the 105 $\mathrm{mg}$ rate by day 31 (Table 1 ) was associated with a significant $(P<$ 0.01 ) increase in dry weight: leaf area (DW/LA) ratio at this $\mathrm{N}$ rate (Table 1). The relative growth rates of SO and VL leaves between days 18 and 30 were lower $(\mathrm{P}<0.05)$ for the $105 \mathrm{mg}$ rate $(0.11$ and $0.18 \mathrm{~cm}^{2} \cdot \mathrm{cm}^{-2}$ per day) than at the 18 or $53 \mathrm{mg}$ rates $(0.25$ and 0.20 , 0.21 , and $0.27 \mathrm{~cm}^{2} \cdot \mathrm{cm}^{-2}$ per day, respectively). The leaf-to-plant dry weight ratio decreased at total plant $\mathrm{N}$ contents above $220 \mathrm{mg}$ in SO and above about $300 \mathrm{mg} \mathrm{N}$ for VL (Fig. 2a), indicating declining leaf growth rate in both rootstock species, despite $\mathrm{N}$ being available.

The smaller shoot: root ratio of SC in Expt. 1 reflected the lower specific fibrous root length (SRL) of this species compared to CM, but there was no significant effect of $\mathrm{N}$ rate on FR length between SO and VL in Expt. 2 (Table 1). There was, however, a significant $(P<0.001)$ reduction in FR/total plant dry weight ratio for slowand fast-growing rootstock species, with increasing plant $\mathrm{N}$ content (Fig. 2b). Fibrous root SRL was significantly higher (by t test) for SO and VL at $53 \mathrm{mg} \mathrm{N} /$ week than at either 18 or $105 \mathrm{mg} \mathrm{N} /$ week by day 31 (Table 1 ).

Water relations. Whole plant transpiration (WPT), which integrated plant water use from 0800 to $1800 \mathrm{HR}$ on various measurement days throughout the 31-day period in Expt. 2, showed an expected variation between days, due primarily to varying temperatures and vapor pressure deficits between measurement days (data not shown). Typical data (day 28) are shown, indicating that, on average, VL had higher total transpiration than SO, particularly at the 53 and $105 \mathrm{mg}$ rates (Table 2). The WPT was significantly $(P=0.02,0.06)$ higher at the $18 \mathrm{mg} \mathrm{N} /$ week rate for SO and VL, than at the 53 or $105 \mathrm{mg} \mathrm{N} /$ week rates. Root hydraulic conductivities measured at day 31 were significantly lower $(P<0.01$, by $t$ test $)$ at the $18 \mathrm{mg}$ rate in comparison to $53 \mathrm{mg} \mathrm{N} /$ week for VL but not SO (Table 2).

Elemental analysis. Total $\mathrm{N}$ concentrations of mature leaves from plants in Expt. 1 always exceeded $30 \mathrm{mg} \cdot \mathrm{g}^{-1}$ for $\mathrm{CM}$ and SC during the 3 1-day uptake period in Expt. 1. In Expt. 2, leaf $\mathrm{N}$
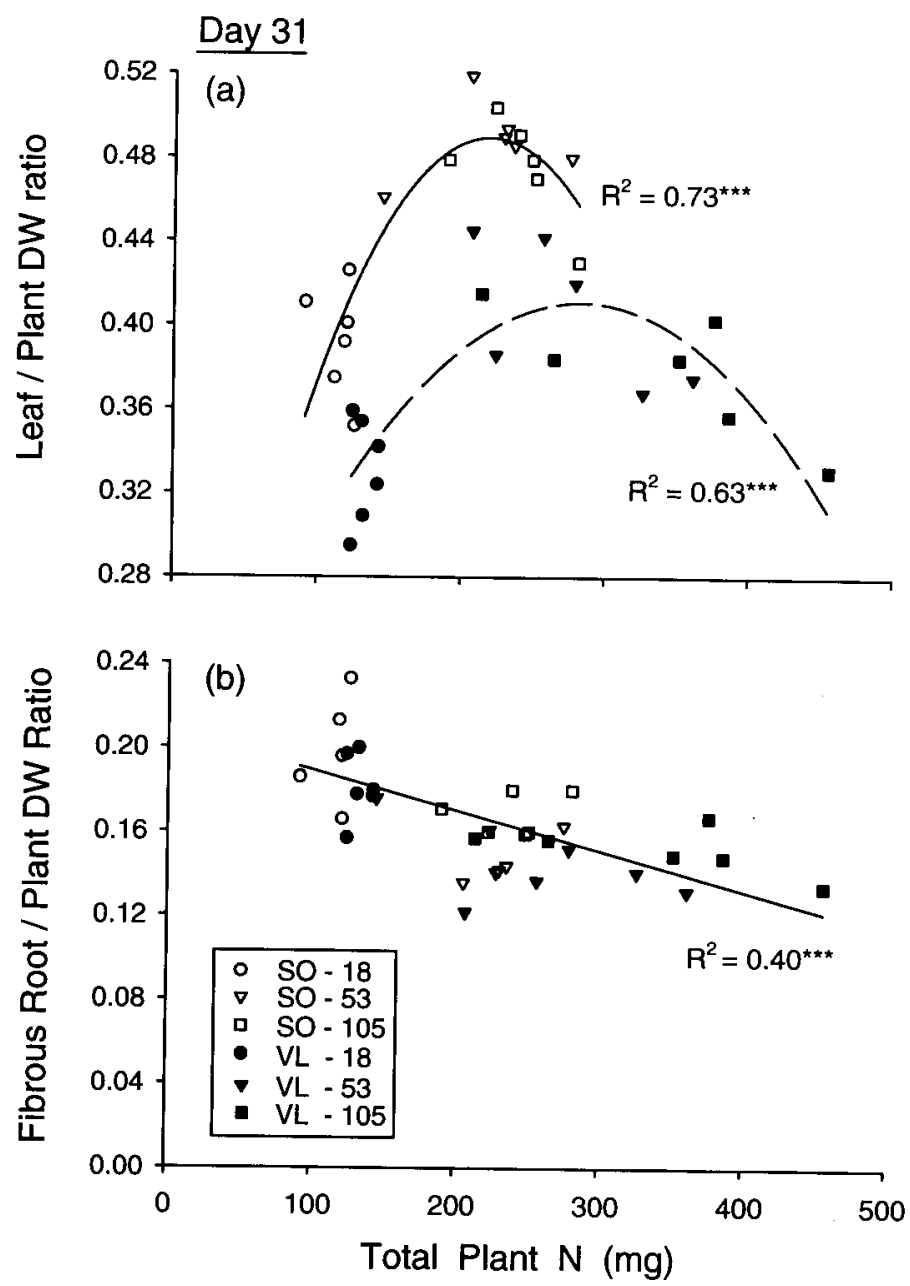

Fig. 2. (a) Leaf and (b) fibrous root to plant dry weight ratios $(n=6)$ of sour orange (SO) and 'Volkamer' lemon (VL) seedlings (Exp. 2),31 days after application of ${ }^{\mathrm{S}} \mathrm{N}$ at each respective $\mathrm{N}$ rate ( $\left.\mathrm{mg} \mathrm{N} / \mathrm{week}\right)$. 
Table 2. Whole-plant transpiration (WPT) on day 28, root conductivity, mature leaf (ML) nitrogen, and total (ah) chlorophyll concentrations for sour orange (SO) and 'Volkamer' lemon (VL) seedlings $(\mathrm{n}=6)$ in Expt. 2.

\begin{tabular}{|c|c|c|c|c|}
\hline Species-N rate & $\begin{array}{c}\text { WP T } \\
(\text { day } 28) \\
\left(\mathrm{mg} \cdot \mathrm{m}^{-2} \cdot \mathrm{s}^{-1}\right)\end{array}$ & $\begin{array}{c}\text { Root } \\
\text { conductivity } \\
\left(\mu \mathrm{g} \cdot \mathrm{m}^{-2} \cdot \mathrm{s}^{-1} \cdot \mathrm{MPa}^{-1}\right)\end{array}$ & $\begin{array}{c}\mathrm{ML} \\
\mathrm{N} \\
\left(\mu \mathrm{mol} \cdot \mathrm{m}^{-2}\right)\end{array}$ & $\begin{array}{c}\text { ML } \\
\text { chlorophyll } \\
\left(\mu \mathrm{mol} \cdot \mathrm{m}^{-2}\right)\end{array}$ \\
\hline $\mathrm{SO}-18 \mathrm{mg}$ & 32.5 & 6.0 & 126 & 285 \\
\hline $\mathrm{SO}-53 \mathrm{mg}$ & 23.2 & 8.5 & 170 & 401 \\
\hline $\mathrm{SO}-105 \mathrm{mg}$ & 23.9 & $\mathrm{~N} \mathrm{M}$ & 250 & 351 \\
\hline Linear & $* * *$ & & $* * *$ & NS \\
\hline Quadratic & $* *$ & & $* * *$ & NS \\
\hline VL-18 mg & 32.3 & 14.1 & 136 & 308 \\
\hline VL-53 mg & 28.5 & 29.3 & 184 & 425 \\
\hline VL-105 mg & 28.0 & NM & 214 & 434 \\
\hline Linear & $*$ & & $* * *$ & $* * *$ \\
\hline Quadratic & $*$ & & $* * *$ & $* *$ \\
\hline \multicolumn{5}{|l|}{ Anova: ( $P$ values $)$} \\
\hline Species & $<0.001$ & $<0.001$ & 0.66 & $<0.001$ \\
\hline Rate & $<0.01$ & $<0.01$ & $<0.001$ & $<0.001$ \\
\hline Species $\times$ rate & 0.06 & 0.04 & 0.10 & 0.05 \\
\hline
\end{tabular}

${ }^{2} \mathrm{NM}=$ not measured; mean separation by $\mathrm{t}$ test.

${ }^{\text {NS,*,****** }}$ Nonignificant or significant at $P<0.10,0.05$, or 0.01 , respectively.

concentrations ranged from $24-28 \mathrm{mg} \cdot \mathrm{g}^{-1} \mathrm{DW}$ at the lowest $\mathrm{N}$ rate, to $29-38$ and $36-43 \mathrm{mg} \cdot \mathrm{g}^{-1}$ at 53 and $105 \mathrm{mg} \mathrm{N} /$ week, respectively

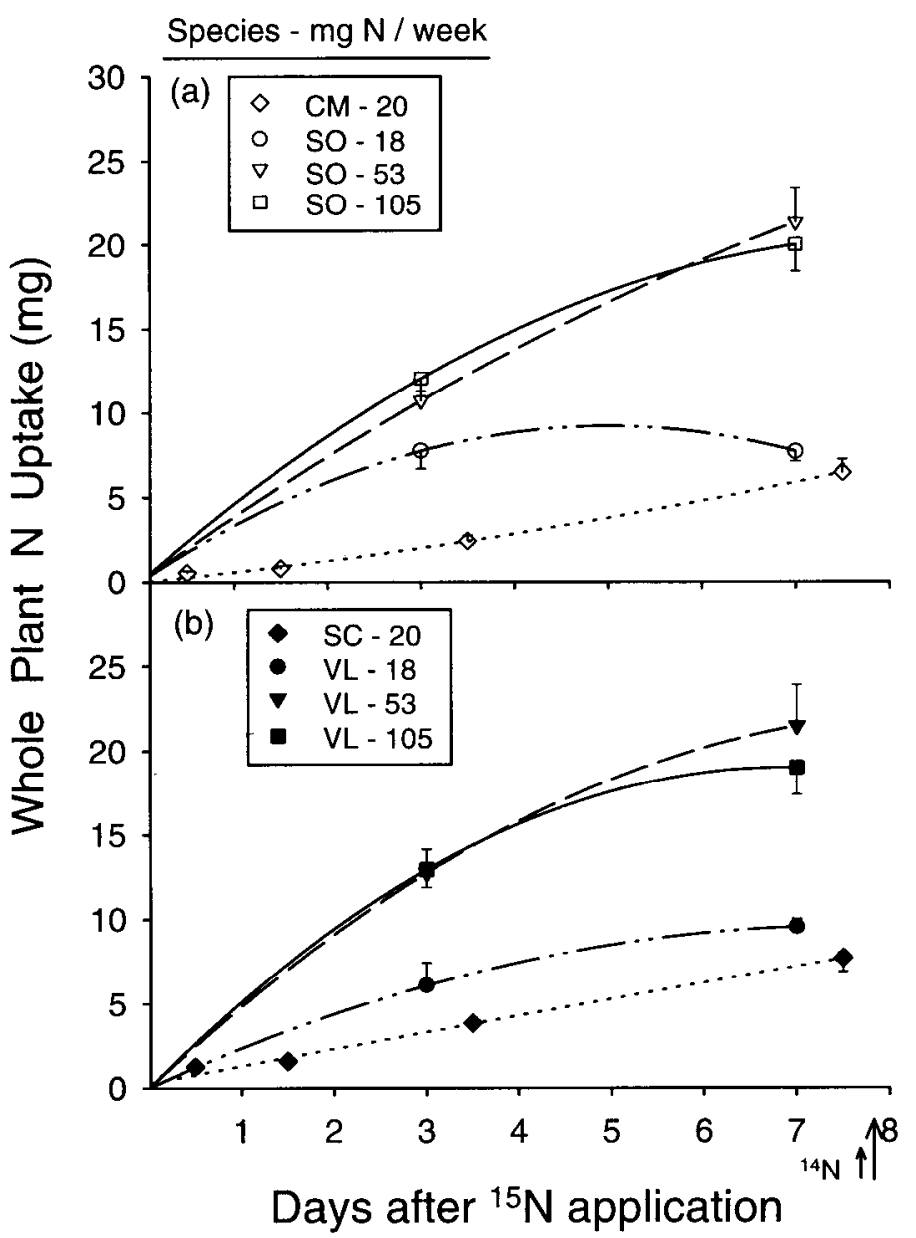

Fig. 3. Whole-plant $\mathrm{N}$ uptake for (a) 'Cleopatra' mandarin (CM) and sour orange (SO), (b) 'Swingle' citrumelo (SC) and 'Volkamer' lemon (VL) seedlings ( $\mathrm{n}=$ 6) during the 7 days after application of ${ }^{15} \mathrm{~N}$ at each respective $\mathrm{N}$ rate (mg N/week). ${ }^{14}$ Nitrogen applications at each rate indicated on the $\mathrm{X}$-axis by small arrow (Expt.

1) and large arrow (Expt. 2). Error bars represent 1 SE from the mean. (data not shown). Leaf nutrient concentrations of Citrus species having different growth rates, however, can be misleading (LeaCox and Syvertsen, 1993). Total leaf N content was, therefore, calculated by multiplying $\mathrm{N}$ concentration by leaf dry weight. Since SO and VL had similar mature leaf dry weights at each $\mathrm{N}$ rate on day 3 (Lea-Cox, 1993), $\mathrm{N}$ content followed the same pattern on day 3 as $\mathrm{N}$ concentration. By day 31, however, VL fertilized at the highest rate had significantly $(P<0.01)$ more leaf $\mathrm{N}(118 \mathrm{mg})$ than SO $(82 \mathrm{mg})$ due in large part to the greater leaf dry weight of VL $(2.8 \mathrm{~g})$ than $\mathrm{SO}(2.3 \mathrm{~g})$. This increase in $\mathrm{N}$ content at day 31 was reflected in the mature leaf $\mathrm{N}$ concentration of $\mathrm{VL}\left(43 \mathrm{mg} \cdot \mathrm{g}^{-1}\right)$, but not for SO $\left(35 \mathrm{mg} \cdot \mathrm{g}^{-1}\right)$.

The macroelement concentrations of CM and SC in Expt. 1 were all in the sufficient range (data not shown) for mature Citrus trees (Koo et al., 1984; Smith, 1966b), although there is not enough data in the literature to indicate whether these ranges are applicable to young seedlings of different growth rates. The concentrations of leaf $\mathrm{P}$ and $\mathrm{K}$ in Expt. 2 were in the optimum to high range (1.7-1.9 $\left.\mathrm{mg} \cdot \mathrm{g}^{-1} \mathrm{P} ; 16-19 \mathrm{mg} \cdot \mathrm{g}^{-1} \mathrm{~K}\right)$ for SO and VL at all harvests. 'Volkamer' lemon leaf $\mathrm{Ca}\left(17-20 \mathrm{mg} \cdot \mathrm{g}^{-1}\right)$ and $\mathrm{Mg}\left(2.3-2.5 \mathrm{mg} \cdot \mathrm{g}^{-1}\right)$ were in the low range, but were more concentrated for SO (20-22 and 3.0-3.7 $\mathrm{mg} \cdot \mathrm{g}^{-1}$, respectively), due to the smaller total leaf area of this species (Table 1).

Nitrogen uptake. Total $\mathrm{N}$ uptake rates on days 3 and 7 (Fig. 3) were calculated by multiplying ${ }^{15} \mathrm{~N}$ uptake (Figs. 4 and 5) by the reciprocal of the atom excess ${ }^{15} \mathrm{~N}$ applied (e.g., $4.906 \mathrm{mg}$ total ${ }^{15} \mathrm{~N}$ $\times 1 / 0.2303$ for SO-53 $\mathrm{mg}$ at day 7). This calculation assumes that there was minimal residual ${ }^{15} \mathrm{~N}$ in the soil pool, since all treatment soils were thorough] y leached with distilled water before ${ }^{15} \mathrm{~N}$ application at day 0 . Nitrogen uptake at 18 and $20 \mathrm{mg} \mathrm{N} /$ week was significantly lower than at the higher rates (Fig. 3), and appeared to be $\mathrm{N}$ limited, because little further ${ }^{15} \mathrm{~N}$ was taken up after 3 days by SO (Fig. 3a) or after 7 days by VL (Fig. 3b). All four rootstock took up similar amounts on $\mathrm{N}\left(50 \%\right.$ to $60 \%=9$ to $\left.12 \mathrm{mg}{ }^{15} \mathrm{~N}\right)$ at the 18 and $20 \mathrm{mg}$ rates (Figs. $4 \mathrm{c}$ and $\mathrm{d}$ and $5 \mathrm{c}$ and d) by 31 days. Total $\mathrm{N}$ uptake at 53 and $105 \mathrm{mg} \mathrm{N} /$ week was similar for SO and VL over the first 7 days. However, uptake of ${ }^{15} \mathrm{~N}$ continued over the entire 3 l-day period at the $105 \mathrm{mg} \mathrm{N}$ rate for SO (Fig. 4a) and especially by VL (Fig. 5a), despite further applications of ${ }^{15} \mathrm{~N}$, which would have diluted the residual ${ }^{15} \mathrm{~N}$ in the soil. By day 31 , the total amount 


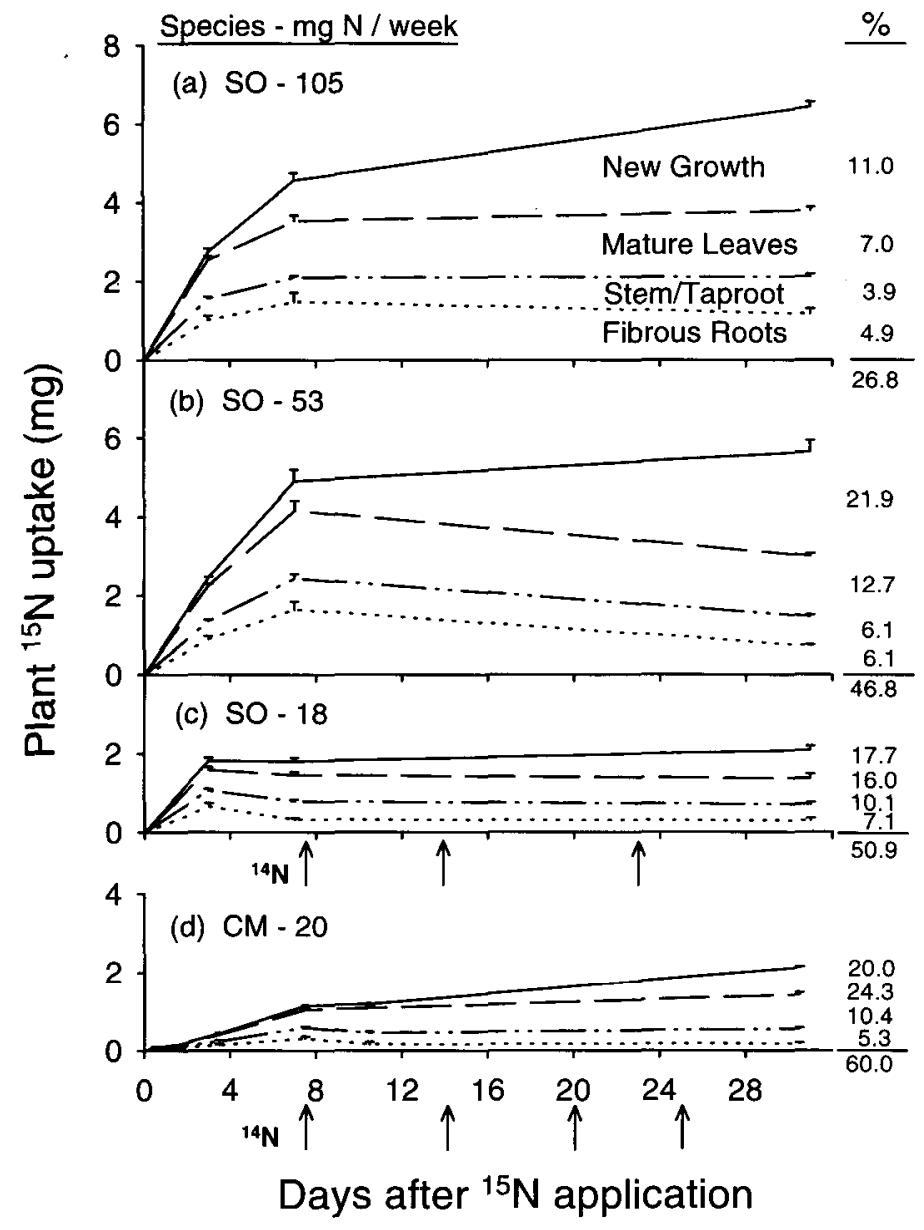

Fig. 4. ${ }^{15}$ Nitrogen uptake into new growth, mature leaf, stem, taproot and fibrous root tissues $(n=6)$ at 3,7 and 31 days after ${ }^{15} \mathrm{~N}$ application for sour orange (SO) seedlings (Expt. 2) and at 0.5, 1.5, 3.5, 7, 11, and 30 days for 'Cleopatra' mandarin (CM) seedlings (Expt. 1), at each respective $\mathrm{N}$ rate (mg N week). Percentage of applied ${ }^{15} \mathrm{~N}$ taken up at each rate is indicated for each tissue. ${ }^{14} \mathrm{Nitrogen}$ applications at each rate indicated on the $\mathrm{x}$-axis by large arrows. Error bars represent $1 \mathrm{SE}$ from the mean.

of $\mathrm{N}$ (i.e., total $\mathrm{N}$ concentration $\mathrm{x}$ total dry weight) in $\mathrm{SO}$ and VL at the $105 \mathrm{mg}$ treatment was greater than the $53 \mathrm{mg}$ treatment, i.e., 28.3 vs. $24.8 \mathrm{mg}$ and 34.2 vs. $26.2 \mathrm{mg}$, respectively. Despite this, the overall uptake efficiency of SO (sum of percentage allocation, Fig. 4) was lowest for the $105 \mathrm{mg}$ treatment $(26.8 \%$, Fig. $4 \mathrm{a})$ compared to that of the 53 and $18 \mathrm{mg}$ treatments $(46.8 \%$ and $50.9 \%$, Fig. $4 \mathrm{~b}$ and c, respectively). However, VL at $105 \mathrm{mg} \mathrm{N} /$ week took up significantly more $\mathrm{N}$ (i.e., $\Sigma \%$ allocation $=0.326 \times$ $105=34.2 \mathrm{mg}$ ) by day 31 than all other treatments (Fig. 5a), reflecting the demand of its greater dry mass accumulation over the period (Fig. 1b).

Nitrogen partitioning. Species differences in ${ }^{15} \mathrm{~N}$ partitioning were evident at the lowest $\mathrm{N}$ rates in both experiments (Figs. $4 \mathrm{c}$ and $\mathrm{d}$ and $5 \mathrm{c}$ and $\mathrm{d}$ ), but differences diminished at the higher rates in Expt. 2 (Figs. $4 \mathrm{a}$ and $\mathrm{b}$ and $5 \mathrm{a}$ and b). A greater proportion of ${ }^{15} \mathrm{~N}$ was partitioned into new growth of both species at the 18 and $53 \mathrm{mg}$ rates than at the $105 \mathrm{mg}$ rate, as evidenced by a large reduction of ${ }^{15} \mathrm{~N}$ content in all other tissues at the 18 and $53 \mathrm{mg}$ treatments for both species by 31 days. Such a reallocation did not occur in the $105 \mathrm{mg}$ treatment, where all tissues maintained or increased their ${ }^{15} \mathrm{~N}$ contents over the time period (Figs. 4a and 5a). Similar amounts [17.6 to $18.3 \mathrm{mg}$ (i.e., $21.9 \%+12.7 \% \times 53 \mathrm{mg}=$ 18.3)] of ${ }^{15} \mathrm{~N}$ were allocated into leaf tissue (new growth and mature leaves) of the 53 and $105 \mathrm{mg}$ rate treatments for SO and VL.
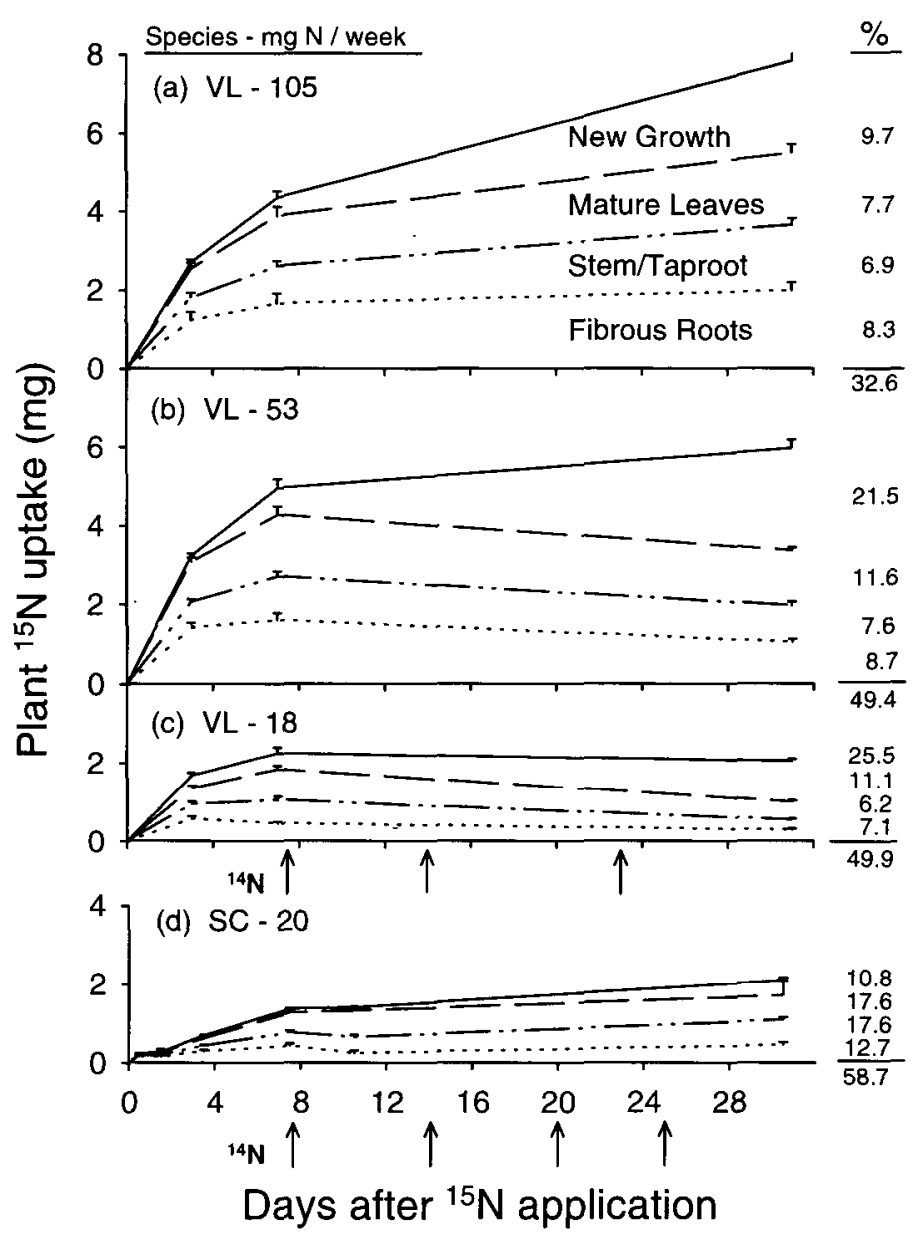

Fig, 5. ${ }^{15}$ Nitrogen uptake into new growth, mature leaf, stem, taproot and fibrous root tissues $(\mathrm{n}=6)$ at 3,7 , and 31 days after ${ }^{15} \mathrm{~N}$ application for 'Volkamer' lemon(VL) seedlings (Exp. 2) and at 0.5, 1.5, 3.5, 7, 11 and 30 days for 'Swingle' citrumelo (SC) seedlings (Expt. 1), at each respective $\mathrm{N}$ rate (mg N/week), Percentage of applied ${ }^{15} \mathrm{~N}$ taken up at each rate on the final day is indicated for each tissue. ${ }^{14}$ Nitrogen applications at each rate indicated on the $\mathrm{x}$-axis by large arrows, Error bars represent $1 \mathrm{SE}$ from the mean.

Leaf $N$ and chlorophyll. Mature leaf $\mathrm{N}$ concentrations were significantly higher at the $105 \mathrm{mg}$ rate than for either the 18 or 53 $\mathrm{mg}$ rates for both species (Table 2). Total mature leaf chlorophyll concentration on a fresh weight basis $\left(\mu \mathrm{mol} \cdot \mathrm{m}^{-2}\right)$, however, exhibited no significant increase at rates above $53 \mathrm{mg} \mathrm{N} /$ week. Sour orange chlorophyll concentrations decreased at the highest $\mathrm{N}$ supply rate, such that the regression analysis showed no significant linear or quadratic effects (Table 2).

Net photosynthetic $\mathrm{CO}_{2}$ assimilation. Net photosynthetic $\mathrm{CO}_{2}$ assimilation showed no significant variation between days, and so only the results from a typical day (day 28) are presented. Leaf $\mathrm{N}$ concentration did not apparently limit $\mathrm{ACO}_{2}$ since there was no difference in $\mathrm{ACO}_{2}$ between $\mathrm{N}$ rate or species (Fig. 6a). The phyllotaxy of 6-month-old seedlings and the spacing of the seedlings in the greenhouse minimized shading effects. Whole-plant $\mathrm{ACO}_{2}$ rates were calculated by multiplying individual leaf $\mathrm{ACO}_{2}$ (day 28) rates by their respective total plant leaf areas on day 31 , solely to assess whether differences entreatment leaf areas could have a large effect on the total assimilation of $\mathrm{C}$ by the plant. Figure $6 \mathrm{~b}$ indicates that total $\mathrm{ACO}_{2}$ per plant increased at a greater rate for SO compared to $\mathrm{VL}$ with increases in total leaf $\mathrm{N}$ up to the $53 \mathrm{mg} \mathrm{N} /$ week rate.

Nitrogen-use efficiency. The increase in mature leaf DW/LA ratio between treatments was taken into account by the calculation 

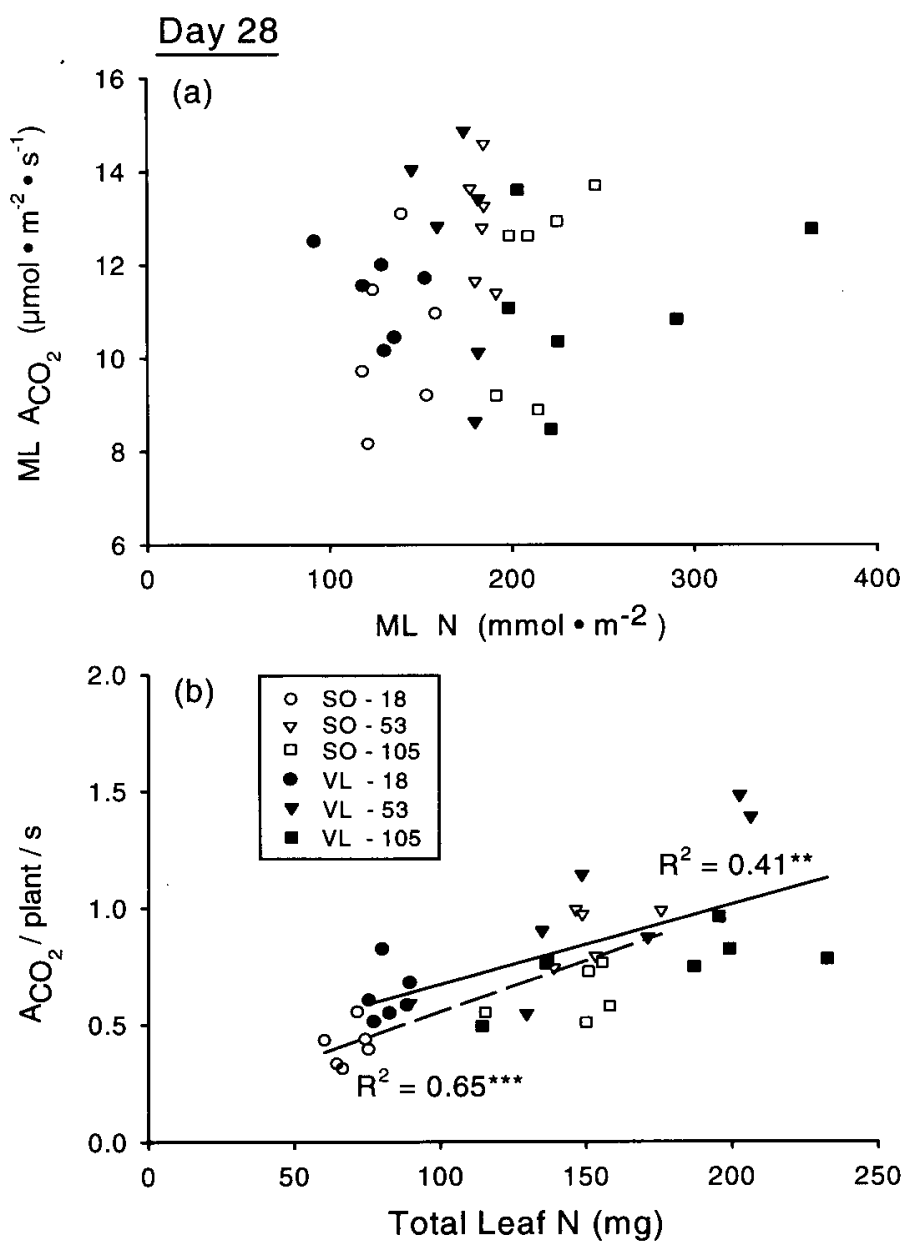

Fig. 6. (a) Mature leaf $\mathrm{CO}_{2}$ assimilation rates on a representative measurement day (day 28) for sour orange (SO) and 'Volkamer' lemon (VL) seedlings $(n=6)$ at each respective $\mathrm{N}$ rate ( $\mathrm{mg} \mathrm{N} /$ week) versus mature leaf $\mathrm{N}$ concentration (leaf area basis); (b) Net plant assimilation (leaf $\mathrm{AcO}_{2} \times$ total leaf area) for sour orange (SO) and 'Volkamer' lemon (VL) seedlings $(n=6)$ on a representative measurement day (day 28) for each respective $\mathrm{N}$ rate (mg N/week) versus total leaf $\mathrm{N}$ content.

of $\mathrm{N}$ use efficiency on a gas exchange basis $\left(\mathrm{NUE}_{\mathrm{A}}\right.$; Mooney and Gulmon, 1979). The NUE decreased as mature leaf $\mathrm{N}$ concentrations increased (Fig. 7a) above $100 \mathrm{mmol} \cdot \mathrm{m}^{-2}$ (about $23 \mathrm{mg} \cdot \mathrm{g}^{-1}$ DW). There were few species differences in this relationship, except for the greater range in $\mathrm{N}$ concentration for VL (Fig. 7a). When $\mathrm{N}$ use efficiencies of SO and VL were calculated on a total dry weight basis (NUEW) and plotted against total plant $\mathrm{N}$ content (Fig. 7b), mean $\mathrm{NUE}_{\mathrm{w}}$ decreased at the same rate as when leaf $\mathrm{NUE}_{\mathrm{A}}$ was plotted against leaf $\mathrm{N}$ concentration (Fig. 7a). Although the relatively slower-growing SO had lower total dry weight and hence total plant $\mathrm{N}, \mathrm{NUE}_{\mathrm{w}}$ decreased at virtually the same rate as VL (Fig. 7b).

Nitrogen loss. Plant ${ }^{15} \mathrm{~N}$ uptake accounted for nearly $60 \%$ of the applied ${ }^{15} \mathrm{~N}$ after 30 days for both rootstock species in Expt. 1 (Table 3). Almost all the ${ }^{15} \mathrm{~N}$ recovered from the soil or leached water after day 1.5 was as ${ }^{15} \mathrm{NO}_{3}$, and soil ${ }^{15} \mathrm{NO}_{3}$ recoveries were minimal after the first 7 days. Total recoveries of the ${ }^{15} \mathrm{~N}$ applied accounted for about $50 \%$ at day 3.5 and $70 \%$ of the ${ }^{15} \mathrm{~N}$ at day 31 . Poor total recoveries early in Expt. 1 were probably due to the small volume $(400 \mathrm{ml})$ of water applied to leach the soil. Soil ${ }^{15} \mathrm{NH}_{4}$ recoveries in Expt. 2 (Tables 4 and 5) were substantially greater at day 3 in comparison to those recovered in Expt. 1 at day 3, particularly for the slower-growing SO species and at the higher rates of fertilization.
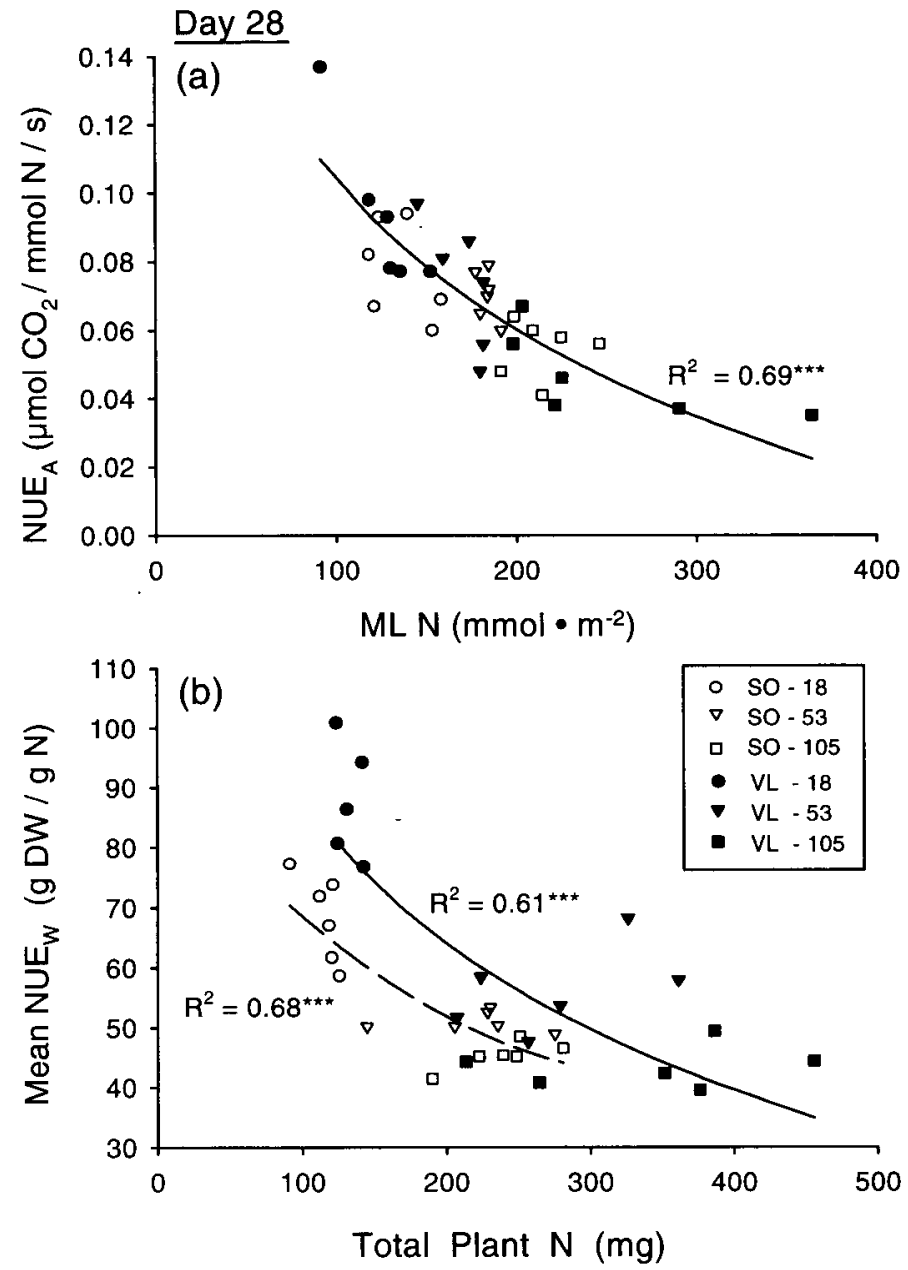

Fig. 7. (a) Gas exchange nitrogen use efficiency (NUE) per mmol leaf $\mathrm{N}$ for sour orange $(\mathrm{SO})$ and Volkamer lemon $(\mathrm{VL})$ seedlings $(n=6)$ for each respective $\mathrm{N}$ rate (mg N/week) versus leaf $\mathrm{N}$ concentration; (b) Dry weight nitrogen-use efficiency $\left(\mathrm{NUE}_{\mathrm{w}}\right)$ per gram total plant dry weight for 'Cleopatra' mandarin (CM), sour orange (SO), 'Swingle' citrumelo (SC) and 'Volkamer' lemon (VL) seedlings $(\mathrm{n}=6)$ for each respective $\mathrm{N}$ rate $(\mathrm{mg} \mathrm{N} /$ week) versus total plant $\mathrm{N}$ content.

In Expt. 2, significantly less soil ${ }^{15} \mathrm{NH}_{4}$ was recovered from VL at the two lower $\mathrm{N}$ application rates (Table 5) compared to SO (Table 4). Soil ${ }^{15} \mathrm{NO}_{3}$ recovery was high at day 3 but declined thereafter in the 18 and $53 \mathrm{mg}$ treatments. Less of a decrease was observed at the $105 \mathrm{mg} \mathrm{N} /$ week rate. Nitrate- ${ }^{15} \mathrm{~N}$ increased significantly in the leached water of the $105 \mathrm{mg}$ rate (counter to the trend in the other two treatments) after day 3, perhaps indicating significant soil vitrification (Lea-Cox, 1993), since the KC1-extractable soil ${ }^{15} \mathrm{NH}_{4}$ decreased significantly at $105 \mathrm{mg} \mathrm{N} /$ week during this time. Between $10 \%$ and $40 \%$ of the ${ }^{15} \mathrm{NO}_{3}$, either directly from the applied ${ }^{15} \mathrm{NO}_{3}$, or nitrified from ${ }^{15} \mathrm{NH}_{4}$ was leached from the pot within the first 3 to 3.5 days from all treatments in both experiments (Tables 3,4, and 5). The effect of increasing $\mathrm{N}$ rate in Expt. 2 was most noticeable at day 31 when negligible amounts of ${ }^{15} \mathrm{~N}$ were leached from the $18 \mathrm{mg}$ treatment (Tables 4 and 5), whereas increasing amounts (14\% to $21 \%$ and $46 \%$ to $60 \%$ for the $53 \mathrm{mg}$ and $105 \mathrm{mg}$ treatments, respectively) of the total applied ${ }^{15} \mathrm{~N}$ were leached as ${ }^{15} \mathrm{NO}_{3}$ from the soil. Electrical conductivities were 0.36 $( \pm 0.07), 0.75( \pm 0.05)$, and $1.88( \pm 0.19) \mathrm{dS} \cdot \mathrm{m}^{-1}$ for leachate volumes $(793 \pm 56 \mathrm{ml})$ from the 18,53 , and $105 \mathrm{mg} \mathrm{N} /$ week treatments respectively, at day 31 . Total $\mathrm{N}$ recoveries exceeded $100 \%$ of that applied at the highest $\mathrm{N}$ rate on day 3 , reflecting the large variability 
Table 3. Percentage of applied ${ }^{15} \mathrm{~N}$ recovered from leachate, soil, and plant fractions of 'Cleopatra' mandarin (CM) and 'Swingle' citrumelo (SC) seedlings $(\mathrm{n}=6) 0.5$ to 31 days after application of ${ }^{15} \mathrm{~N}$, at $20 \mathrm{mg}$ total $\mathrm{N} /$ week in Expt. 1. Soil and leached $\mathrm{NH}_{4}$ and $\mathrm{NO}_{3}$ budgets presented as percentage recovered from $\mathrm{N}$ applied as $0.5{ }^{15} \mathrm{~N} \mathrm{H}_{4}-\mathrm{N}: 0.5{ }^{15} \mathrm{~N} \mathrm{O}_{3}-\mathrm{N}$ at Day 0 . Numbers in parentheses after the totals represent 1 SE about the mean.

\begin{tabular}{|c|c|c|c|c|c|c|c|}
\hline \multirow[b]{2}{*}{ Species-N rate } & \multirow[b]{2}{*}{ Days } & \multicolumn{6}{|c|}{ Percentage } \\
\hline & & Plant & Soil $\mathrm{NH}_{4}$ & Soil $\mathrm{NO}_{3}$ & Leached $\mathrm{NH}_{4}$ & Leached $\mathrm{NO}_{3}$ & Total \\
\hline \multirow[t]{6}{*}{ CM-20 mg } & 0.5 & 2.7 & 1.6 & 3.4 & 0.1 & 13.4 & $21.2( \pm 3.5)$ \\
\hline & 1.5 & 4.1 & 1.4 & 3.4 & 0.1 & 11.4 & $20.3( \pm 1.9)$ \\
\hline & 3.5 & 12.1 & 0.0 & 1.0 & 0.0 & 38.9 & $52.0 \quad( \pm 3.5)$ \\
\hline & 7 & 32.3 & 0.1 & 0.4 & 0.1 & 34.3 & $67.1( \pm 3.4)$ \\
\hline & 11 & 33.4 & 0.1 & 0.6 & 0.2 & 27.7 & $61.9(+4.5)$ \\
\hline & 31 & 60.0 & 0.0 & 0.1 & 0.0 & 7.3 & $67.4 \quad( \pm 2.6)$ \\
\hline \multirow[t]{6}{*}{$\mathrm{SC}-20 \mathrm{mg}$} & 0.5 & 6.3 & 0.6 & 5.1 & 0.1 & 12.2 & $24.2( \pm 3.2)$ \\
\hline & 1.5 & 7.9 & 0.8 & 3.0 & 1.4 & 14.8 & $27.9( \pm 2.3)$ \\
\hline & 3.5 & 19.2 & 0.0 & 1.5 & 0.2 & 28.5 & $49.5( \pm 1.6)$ \\
\hline & 7 & 38.4 & 0.1 & 0.2 & 0.2 & 34.7 & $73.7 \quad( \pm 5.1)$ \\
\hline & 11 & 39.4 & 0.1 & 0.5 & 0.7 & 25.2 & $65.8( \pm 4.8)$ \\
\hline & 31 & 58.7 & 0.0 & 0.0 & 0.3 & 13.0 & $72.0 \quad( \pm 2.8)$ \\
\hline \multicolumn{8}{|c|}{ Anova: $(P$ values $)$} \\
\hline \multicolumn{2}{|c|}{ Species } & $<0.001$ & 0.92 & 0.59 & 0.27 & 0.98 & \\
\hline \multicolumn{2}{|c|}{ Time } & $<0.01$ & 0.33 & $<0.001$ & 0.96 & $<0.001$ & \\
\hline \multicolumn{2}{|c|}{ Species $\times$ time } & 0.94 & 0.99 & 0.14 & 0.97 & 0.14 & \\
\hline
\end{tabular}

$( \pm 20 \%$ to $30 \%)$ of the soil NH, data for SO and VL (Tables 4 and 5).

Green algae grew on the soil surface during the first 8 weeks in Expt. 2, particularly on those pots fertilized at the highest rate. This organic material was scraped off the soil surface before application of ${ }^{15} \mathrm{~N}$ but may have been indicative of an increase in microorganism activity in the soil (Lea-Cox, 1993). In a related observation, water leached from soils fertilized at the $105 \mathrm{mg}$ rate which had the highest EC, consistently appeared clear in comparison to the increased turbidity of the leachates from the $53 \mathrm{mg}$ and especially the $18 \mathrm{mg}$ N/week treatment.

\section{Discussion}

Growth of 6-month-old SO and VL seedlings was limited by N supply at $18 \mathrm{mg} \mathrm{N} /$ week, regardless of their different growth rates. Leaf $\mathrm{N}$ concentrations of $25 \mathrm{mg} \cdot \mathrm{g}^{-1}$ were maintained at this low $\mathrm{N}$ rate in both rootstock species because of the limited plant growth and lower leaf area than the higher $\mathrm{N}$ treatments. Total plant dry weight of SO and VL increased at 53 and $105 \mathrm{mg} \mathrm{N} /$ week, with no difference between these rates, even though mature leaf $\mathrm{N}$ concentrations were higher at the $105 \mathrm{mg} \mathrm{N} /$ week rate. New leaf growth at $\mathrm{N}$ concentrations above $18 \mathrm{mg} \mathrm{N} /$ week appeared to be a driving variable for $\mathrm{N}$ uptake. There was no significant increase in total leaf area or total plant dry weight above $53 \mathrm{mg} \mathrm{N} /$ week, although leaf $\mathrm{N}$ concentration and total plant $\mathrm{N}$ was greater at the $105 \mathrm{mg}$ rate by the end of the study. Thus, there appeared to be a considerable increase in $\mathrm{N}$ uptake at the $105 \mathrm{mg}$ rate, without new vegetative growth. There was, however, an increase in leaf weight per unit area at this rate and hence the $\mathrm{N}$ concentration of these leaves increased on an area basis with increasing $\mathrm{N}$ availability.

The larger shoot : root ratios of slower- and faster-growing species at higher $\mathrm{N}$ rates is consistent with data in the literature

Table 4. Percentage of applied ${ }^{15} \mathrm{~N}$ recovered from leachate, soil, and plant fractions of sour orange (SO) seedlings $(\mathrm{n}=6)$ over 31 days, at three $\mathrm{N}$ rates $\left(18,53\right.$ and $105 \mathrm{~m}$ total $\mathrm{N} /$ week) in Expt. 2. Soil and leached $\mathrm{NH}_{4}$ and $\mathrm{NO}_{3}$ budgets presented as percentage recovered from $\mathrm{N}$ applied as $0.5{ }^{15} \mathrm{NH}_{4}-\mathrm{N}: 0 .{ }^{15} \mathrm{NO}_{3}-\mathrm{N}$ at day 0 . Numbers in parentheses after the totals represent $1 \mathrm{SE}$ about the mean.

\begin{tabular}{|c|c|c|c|c|c|c|c|}
\hline \multirow[b]{2}{*}{ Species-N rate } & \multirow[b]{2}{*}{ Days } & \multicolumn{6}{|c|}{ Percentage } \\
\hline & & Plant & Soil $\mathrm{NH}_{4}$ & Soil $\mathrm{NO}_{3}$ & Leached $\mathrm{NH}_{4}$ & Leached $\mathrm{NO}_{3}$ & Total \\
\hline \multirow[t]{3}{*}{ SO-18 mg } & 3 & 44.2 & 13.0 & 11.2 & 2.4 & 28.2 & $99.0 \quad( \pm 13.5)$ \\
\hline & 7 & 44.0 & 12.8 & 0 & 0.2 & 5.0 & $62.0( \pm 4.9)$ \\
\hline & 31 & 50.9 & 5.5 & 1.2 & 0 & 1.0 & $58.6( \pm 2.5)$ \\
\hline \multirow[t]{3}{*}{$\mathrm{SO}-53 \mathrm{mg}$} & 3 & 20.4 & 22.8 & 17.9 & 2.9 & 34.5 & $98.5( \pm 7.5)$ \\
\hline & 7 & 40.6 & 3.1 & 2.5 & 0.2 & 28.7 & $75.1 \quad( \pm 4.0)$ \\
\hline & 31 & 46.8 & 0 & 1.2 & 0.3 & 21.3 & $69.6( \pm 2.5)$ \\
\hline \multirow[t]{3}{*}{$\mathrm{SO}-105 \mathrm{mg}$} & 3 & 11.5 & 57.4 & 17.7 & 7.2 & 28.4 & $122.2( \pm 9.8)$ \\
\hline & 7 & 19.0 & 6.5 & 8.9 & 9.9 & 47.7 & $92.0( \pm 7.0)$ \\
\hline & 31 & 26.8 & 6.2 & 1.8 & 7.8 & 45.5 & $88.2( \pm 6.6)$ \\
\hline \multicolumn{8}{|c|}{ Anova: ( $P$ values $)$} \\
\hline \multicolumn{2}{|c|}{ Time } & $<0.001$ & $<0.001$ & $<0.001$ & $<0.01$ & $<0.01$ & \\
\hline \multicolumn{2}{|l|}{ Rate } & $<0.001$ & $<0.001$ & $<0.01$ & $<0.001$ & $<0.001$ & \\
\hline \multicolumn{2}{|l|}{ Time $\times$ rate } & 0.50 & $<0.01$ & 0.31 & 0.02 & $<0.001$ & \\
\hline
\end{tabular}


Table 5. Percentage of applied ${ }^{15} \mathrm{~N}$ recovered from leachate, soil, and plant fractions of 'Volkamer' lemon $(\mathrm{VL})$ seedlings $(\mathrm{n}=6)$ over 31 days, at three $\mathrm{N}$ rates $\left(18,53\right.$, and $105 \mathrm{mg}$ total $\mathrm{N} /$ week) in Expt. 2. Soil and leached $\mathrm{NH}_{4}$ and $\mathrm{NO}_{3}$ budgets presented as percentage recovered from $\mathrm{N}$ applied as $0.5{ }^{15} \mathrm{NH}_{4}-\mathrm{N}: 0.5{ }^{15} \mathrm{NO}_{3}-\mathrm{N}$ at day 0 . Numbers in parentheses after the totals represent $1 \mathrm{SE}$ about the mean.

\begin{tabular}{|c|c|c|c|c|c|c|c|}
\hline \multirow[b]{2}{*}{ Species-N rate } & \multirow[b]{2}{*}{ Days } & \multicolumn{6}{|c|}{ Percentage } \\
\hline & & Plant & Soil $\mathrm{NH}_{4}$ & Soil $\mathrm{NO}_{3}$ & Leached & $\mathrm{NH}_{4}$ Leached & Total \\
\hline \multirow[t]{3}{*}{$\mathrm{VL}-18 \mathrm{mg}$} & 3 & 40.7 & 0 & 11.6 & 0.2 & 21.5 & $74.0 \quad( \pm 7.0)$ \\
\hline & 7 & 54.5 & 3.6 & 0 & 0.2 & 4.1 & $62.4 \quad( \pm 3.7)$ \\
\hline & 31 & 49.9 & 1.1 & 0 & 0 & 0.8 & $51.8 \quad( \pm 1.6)$ \\
\hline \multirow[t]{3}{*}{ VL-53 mg } & 3 & 26.7 & 4.6 & 34.4 & 2.9 & 28.9 & $97.5 \quad( \pm 11.4)$ \\
\hline & 7 & 40.9 & 0.5 & 0.5 & 0.1 & 21.6 & $63.6( \pm 4.6)$ \\
\hline & 31 & 49.4 & 0.7 & 1.0 & 0.3 & 14.4 & $65.8( \pm 4.6)$ \\
\hline \multirow[t]{3}{*}{ VL-105 mg } & 3 & 11.2 & 45.2 & 19.6 & 11.6 & 40.1 & $127.7( \pm 11.1)$ \\
\hline & 7 & 18.1 & 1.9 & 6.5 & 10.2 & 55.3 & $92.8 \quad( \pm 4.4)$ \\
\hline & 31 & 32.6 & 2.9 & 9.8 & 3.7 & 59.8 & $108.8( \pm 4.4)$ \\
\hline \multicolumn{8}{|c|}{ Anova: ( $P$ values $)$} \\
\hline \multicolumn{2}{|c|}{ Time } & $<0.001$ & $<0.001$ & $<0.001$ & $<0.001$ & 0.02 & \\
\hline \multicolumn{2}{|l|}{ Rate } & $<0.001$ & $<0.001$ & $<0.001$ & $<0.001$ & $<0.001$ & \\
\hline \multicolumn{2}{|l|}{ Time $\times$ rate } & 0.44 & $<0.001$ & $<0.01$ & $<0.001$ & $<0.001$ & \\
\hline
\end{tabular}

where the proportion of dry weight allocated to roots decreases under high $\mathrm{N}$ availability (Tolley-Henry and Raper, 1991 ). The decrease in relative growth rate, shoot : root ratio, specific root length and total leaf area of SO and VL at the $105 \mathrm{mg} \mathrm{N}$ rate may have been a function of the periodicity of shoot growth or resource allocation in this treatment over the 4-week period. Leaf DW/LA ratio increased with $\mathrm{N}$ rate, increasing $\mathrm{N}$ storage in the leaf of both species by day 31, which may have also reflected the leaf aging process (Syvertsen et al., 1981).

The similarity in the uptake and partitioning of $\mathrm{N}$ among the various species within each rate was remarkable considering their differences in growth rate. Despite higher leaf $\mathrm{N}$ concentrations for $\mathrm{CM}$ and SC fertilized initially at 50 and then $20 \mathrm{mg} \mathrm{N} /$ week (Expt. 1) in comparison to SO and VL at $18 \mathrm{mg} \mathrm{N} /$ week (Expt. 2), total ${ }^{\text {is }} \mathrm{N}$ uptake was similar for all four species by day 31 . More importantly, leaf $\mathrm{N}$ concentrations of plants increased with $\mathrm{N}$ rate, and were maintained throughout the 31 days. Thus, $\mathrm{N}$ supply above 53 $\mathrm{mg} \mathrm{N} /$ week was sufficient to maintain a high average RGR for SO and VL seedlings. At the $105 \mathrm{mg} \mathrm{N} /$ week rate, the ${ }^{15} \mathrm{~N}$ uptake was adequate to maintain the ${ }^{15} \mathrm{~N}$ content of all tissues and support the new growth requirements with the extra $\mathrm{N}$ going into storage reflected in increased leaf thickness. At $53 \mathrm{mg} \mathrm{N} /$ week, however, reallocation of ${ }^{15} \mathrm{~N}$ from $\mathrm{ML}$ and other tissues was necessary to support the demand of the new vegetative growth. This may indicate that $53 \mathrm{mg} \mathrm{N} /$ week over a longer-term or under different environmental conditions may have been insufficient to support as much growth as $105 \mathrm{mg} \mathrm{N} /$ week.

It is possible that the extra $\mathrm{N}$ content of leaves at the $105 \mathrm{mg}$ rate provided an additional benefit in increasing chlorophyll content (at least in VL) and hence the long-term NUE of the plants. Nitrogen in leaves constitutes a large part of the $\mathrm{N}$ reserves of Citrus trees (Moreno and Garcia-Martinez, 1984). Evans (1989) indicated that leaf chlorophyll concentration increases linearly with total leaf $\mathrm{N}$ from $50-200 \mathrm{mmol} \cdot \mathrm{m}^{-2}$ for a number of different species grown under high light conditions with variable $\mathrm{N}$ nutrition. Our data indicate that this relationship is asymptotic, as the increase in leaf $\mathrm{N}$ concentration over this range did not increase leaf chlorophyll concentration in SO. When total leaf areas per plant were used to estimate whole-plant assimilation, it was clear that high $\mathrm{N}$ supply increased total plant assimilation by increasing the leaf area. The significant decrease in $\mathrm{N}$ use efficiencies indicate that at least under these conditions, the $\mathrm{ACO}_{2}$ of Citrus species did not increase with increasing leaf $\mathrm{N}$ above a threshold of $100 \mathrm{mmol} \cdot \mathrm{m}^{-2}$ (about $23 \mathrm{mg} \cdot \mathrm{g}^{-1}$ ) (Syvertsen, 1987). These data support the contention of Lloyd et al. (1992) that low $\mathrm{NUE}_{\mathrm{A}}$ in Citrus species may be a consequence of decreasing proportions of leaf $\mathrm{N}$ being allocated to the photosynthetic process as $\mathrm{N}$ concentration increases.

Available $\mathrm{N}$ (from the single ${ }^{15} \mathrm{~N}$ application) continued to be taken up over a 31 -day period, even though additional ${ }^{14} \mathrm{~N}$ applications diluted the tracer. The significant increases in leaf $\mathrm{N}$ concentrations of $\mathrm{SO}$ and $\mathrm{VL}$ were a result of the additional $\mathrm{N}$ fertigations, since a lack of leaching between fertigations increased soil $\mathrm{N}$ availability. Nevertheless, all $\mathrm{N}$ uptake rates reported here are considerably lower than those suggested by Bitcover and Wander (1950) and show that $\mathrm{N}$ uptake is strongly dependent on the relative growth rate of the species and total $\mathrm{N}$ availability. The trees in their study were much larger, however, and total nutrient uptake is obviously correlated to tree size. The efficiency of uptake was inversely related to the amount supplied, which has been generally observed infield experiments (Smith, 1966a). Extrapolation of the uptake-efficiencies to 59 days [e.g. (about $30 \% \times(105 \mathrm{mg}) \times 4$ applications $\times 59 / 31$ days $)=240 \mathrm{mg}$ ] shows that our data were very similar to those of Wallace $(1954)$ [i.e. $(39 \% \times 485 \mathrm{mg})=190 \mathrm{mg}$ ].

Half of the ${ }^{15} \mathrm{~N}$ applied was in the form of ${ }^{15} \mathrm{NH}_{4}^{+}$. The percentage of residual soil ${ }^{15} \mathrm{NH}_{4}^{+}$decreased to very low levels within 3 days in Expt. 1 and 7 days (depending on rate) in Expt. 2. This suggested either rapid preferential plant uptake of $\mathrm{NH}_{4}^{+}$, microbial conversion to $\mathrm{NO}_{3}$, and/or adsorption to soil organic matter (Ardakani et al., 1973). A greater proportion of the " $\mathrm{N}$ was found as ${ }^{15} \mathrm{NO}_{3}$ than as ${ }^{15} \mathrm{NH}_{4}{ }^{+}$in the leached water, particularly at the highest (105 mg N/week) rate. A large proportion of the "N applied, 12910 to $48 \%$, could not be accounted for in these experiments, particularly after the first 7 days and at the lower $\mathrm{N}$ application rates. Similar fractions have been unaccounted for in other ${ }^{15} \mathrm{~N}$ experiments (Broadbent and Clark, 1965) and with mature Citrus ${ }^{15} \mathrm{~N}$ experiments (Dasberg, 1987, Lea-Cox and Syvertsen, 1992). Insufficient leaching of the soil profiles probably contributed to the poor recoveries of ${ }^{15} \mathrm{~N}$ from the first two harvests in Expt. 1. The small leaching volume used in Expt. 1 (400 $\mathrm{ml}$ ) may have been insufficient to elute the entire soil volume, even though this volume was $115 \%$ of the average void volume of the pot. As the ${ }^{15} \mathrm{~N}$ moved lower through the soil profile before later 
harvests, it was more likely to be eluted by this leaching application of distilled water. In addition, the surface growth of algae implies that there may have been increased microbial competition for $\mathrm{N}$ in the soils at the lower $\mathrm{N}$ rates (Lea-Cox, 1993).

Coupled with the plant growth data, the large amount of $\mathrm{NO}_{3}$ in the leached water at the higher rates provided evidence that $\mathrm{N}$ availability at the 53 and $105 \mathrm{mg}$ rates did not limit plant growth or the rate of $\mathrm{N}$ uptake. The potential for leaching losses from $\mathrm{N}$ applications above those immediately required for plant growth therefore, appears high in small volume containers of sand. Increasing the $\mathrm{N}$ supply above $53 \mathrm{mg} \mathrm{N} /$ week apparently only increased the residual soil $\mathrm{N}$ and the likelihood of $\mathrm{N}$ being leached below the root zone, for slow (SO) and fast-growing (VL) rootstock. Maust and Williamson (1994) stated that the critical concentration for the growth of young budded Citrus rootstock was between 15 and $19 \mathrm{mg}$ N/liter. They applied about 1 liter of their nutrient solutions on a daily basis, which equates to about 105-133 mg N/week. In reconciling these two studies, it is apparent that about $105 \mathrm{mg} \mathrm{N} /$ week maybe required for maintaining the growth of faster-growing rootstock, but excessive for slowergrowing species. In addition, a substantial portion of the Nat this rate is able to be leached, if applied on a weekly basis. Supplying low concentrations of $\mathrm{N}$ daily (i.e., $8-15 \mathrm{mg} \mathrm{N} /$ day per seedling) should, however, substantially reduce $\mathrm{N}$ leaching from sandy soils, and maintain the high growth rates of Citrus seedlings up to 8 months old.

\section{Literature Cited}

Agren, G. 1985. Theory for growth of plants derived from the nitrogen productivity concept. Physiol. Plant. 64: 17-28.

Ardakani, M.S., J.T. Rebock, and A.D. McLaren. 1973, Oxidation of ammonium to nitrate in a soil column. Soil. Sci. Amer. Proc. 38:96-99.

Bitcover, E.A. and I.W. Wander, 1950, Some observations on nitrite formation and the absorption of nitrogen by Citrus. Pl. Physiol. 25:461-468.

Bremner, J.M. 1965. Inorganic forms of nitrogen, p, 1179-1257. In: Black, C.A., F.E. Clark, D.D. Evans, L.E. Ensminger and J.L. White (eds.). Methods of soil analysis, Part 2. Amer. Soc. Agron. Madison, Wis.

Bremner, J.M. and D.R. Keeney. 1966. Determination and isotope-ratio analysis of different forms of nitrogen in soils: 3. Exchangeable ammonium, nitrate and nitrite by extraction-distillation methods. Soil Sci. Soc. Amer. Proc. 30:577-582.

Broadbent, F.E. and F.E. Clark. 1965, Denitrification, p. 344-359. In: W.V. Bartholomew and F.E. Clark (eds.). Soil nitrogen. Amer. Soc. Agron., Madison, Wis.

Cabrera, M.L. and D.E. Kisel. 1989. Review and simplification of calculations in ${ }^{15} \mathrm{~N}$ tracer studies. Fert. Res. 20:11-15.

Chapman, H.D. and G.F. Liebig. 1937. The effects of various nitrate concentrations on the growth and composition of sweet orange seedlings, Soil. Sci. Soc. Amer. Proc. 2:359-365.

Clesceri, L.S., A.E. Greenberg, and R.R. Trussell. 1989. Standard methods for the examination of water and wastewater. 17th ed. Amer. Public Health Assn., Washington, D.C.

Dasberg, S., 1987. Nitrogen fertilization in Citrus orchards. Plant Soil 100: 1-9.

DeJong, T.M. 1982. Leaf nitrogen content and $\mathrm{CO}_{2}$ assimilation capacity in peach. J. Amer. Soc. Hort. Sci. 107:955-959.

DeJong, T.M. and D.A. Philips. 1981. Nitrogen stress and apparent photosynthesis in symbiotically y-grown Pisum sativum L. Plant Physiol. 68:309-313.

Evans, J.R. 1989. Photosynthesis and nitrogen relationships in leaves of $\mathrm{C}_{3}$ plants. Oecologia 78:9-19.

Gaines, T.P. and G.A. Mitchell. 1979. Chemical methods for soil and plant analysis, p. 52. Agronomy handbook 1. Coastal Plain Expt. Sta., Univ. of Ga.

Graham, J.H. and J.P. Syvertsen. 1984. Influence of vesicular-arbuscular mycorrhiza on the hydraulic conductivity of roots of two Citrus rootstock. New Phytol. 97:277-284.

Haas, A.R.C. 1937. Nitrogen in relation to the growth of Citrus cuttings in solution cultures. Plant Physiol. 12: 163-172.

Hauck, R.D. and J.M. Bremner. 1976. Use of tracers for soil and fertilizer nitrogen research. Adv. Agron. 28:219-266.

Hesketh, J. D., W.L. Ogren, M.E. Hageman, and D.B. Peters. 1981. Correlations among leaf $\mathrm{CO}_{2}$-exchange rates, areas and enzyme activities among soybean cultivars. Photosyn. Res. 2:21-30.

Ingestad, T. and A-B. Lund. 1979. Nitrogen stress in birch seedlings. I. Growth technique and growth. Physiol. Plant. 45: 137-148.

Koo, R.C. J., C.A. Anderson, I. Stewart, D.P.H. Tucker, D.V. Calvert, and H.K. Wutscher. 1984. Recommended fertilizers and nutritional sprays for Citrus. IFAS Bul. 536D. Univ. of Fla. Gainesville.

Lea-Cox, J.D. 1989. Macroelement nutrition of container-grown Citrus nursery stock in pine bark substrates. MS thesis, Univ. of Natal, Pietermaritzburg, South Africa.

Lea-Cox, J.D. 1993. Nitrogen uptake, nitrogen use-efficiency and nitrogen leaching losses of Citrus. PhD diss. Univ. of Fla., Gainesville,

Lea-Cox, J.D. and J.P. Syvertsen. 1992. Salinity increases nitrogen leaching losses from Cirrus in sandy soils. Proc. Fla. State Hort. Soc. 105:76-82.

Lea-Cox, J.D. and J.P. Syvertsen. 1993. Salinity reduces water use and nitrate-N use-efficiency of Citrus. Ann. Bot. 72:47-54,

Littell, R.C. 1989, Statistical analysis of experiments with repeated measurements. HortScience 24:37-40.

Lloyd, J., J.P. Syvertsen, P.E. Kriedemann, and G.D. Farquhar. 1992. Low conductance for $\mathrm{CO}_{2}$ diffusion from stomata to the sites of carboxylation in leaves of woody species, Plant Cell Environ. 15:873-899.

Lugg, D.G. and T.R. Sinclair. 1981. Seasonal changes in photosynthesis of fieldgrown soybean leaflets. 2. Relation to nitrogen content. Photosynthetic 15:138144.

Maust, B.E. and J.G. Williamson. 1994, Nitrogen nutrition of containerized Citrus nursery plants. J. Amer. Soc. Hort. Sci. 119: 195-201.

McDonald, A.J.S., T. Ericsson, and T. Ingestad, 1991. Growth and nutrition of tree seedlings, p. 199-220. In: A.S. Raghavendra (cd.). Physiology of trees. Wiley, New York

Montgomery, D.C. 1984. Design and analysis of experiments, p. 189-201. 2nd ed. Wiley, New York.

Mooney, H.A., P.J. Ferrar, and R.O. Slatyer. 1978. Photosynthetic capacity and carbon allocation patterns in diverse growth forms of Eucalyptus. Oecologia 36:103-111.

Mooney, H.A. and S.L. Gulmon. 1979. Environmental and evolutionary constraints on the photosynthetic characteristics of higher plants. In: D.T. Solbrig, S. Jain, G.B. Johnson, and P.H. Raven (eds.). Topics in plant population biology. Columbia Univ. Press, New York. p. 316-337.

Moran, R. and D. Porath. 1980. Chlorophyll determinations in intact tissues using N,N-dimethyl formamide, Plant Physiol. 65:478-479.

Moreno, J. and J.L. García-Martinez. 1984, Nitrogen accumulation and mobilization in Citrus leaves throughout the annual cycle. Physiol. Plant. 61:429434.

Ott, L. 1988. An introduction to statistical methods and analysis, p. 420. 3rd ed. In: M. Payne (cd,). PWS-Kent, Boston.

Radin, J.W. and J.S. Boyer. 1982. Control of leaf expansion by nitrogen nutrition in sunflower plants. Role of hydraulic conductivity and turgor. Plant Physiol. 69:771-775.

Rufty, Jr., T.W, C.T. MacKown, and R.J. Volk. 1990. Alterations in nitrogen assimilation and partitioning in nitrogen stressed plants. Physiol. Plant. 79: 8589.

Sinclair, T.R. 1992. Mineral nutrition and plant growth response to climate change. J. Expt. Bot. 43:1141-1146.

Smith, P.F. 1966a. Citrus nutrition, p. 174-207, In: N.F. Childers (cd.). Nutrition of fruit crops. Hort. Publ,, Rutgers, N.J.

Smith, P.F. 1966b. Leaf analysis of Citrus, p. 208-228. In: N.F. Childers (cd.) Nutrition of fruit crops. Hort. Publ., Rutgers, N.J.

Syvertsen, J.P. 1985. $\mathrm{CO}_{2}$ assimilation and water use-efficiency of young expanding Citrus leaves. Acta Hort. 171:229-236.

Syvertsen, J.P. 1987. Nitrogen content and $\mathrm{CO}_{2}$ assimilation characteristics of Citrus leaves, HortScience 22:289-291.

Syvertsen, J.P., M.L. Smith, Jr., and J.C. Allen. 1981. Growth rate and water relations of Cirrus leaf flushes. Ann. Bot. 47:97-105.

Tennant, D. 1975. A test of a line intersect method of estimating root length, J. Ecol. 63:995-1001.

Tolley-Henry, L. and C.D. Raper, Jr., 1991. Soluble carbohydrate allocation to roots, photosynthetic rate of leaves, and nitrate assimilation as affected by nitrogen stress and irradiance, Bot. Gaz. 152:23-33.

Wallace, A. 1954. Ammonium and nitrate nitrogen absorption by Citrus. Soil Sci. 78:89-94. 